\title{
Evaluation of the
}

Social Water Management Practices in Saighan Valley

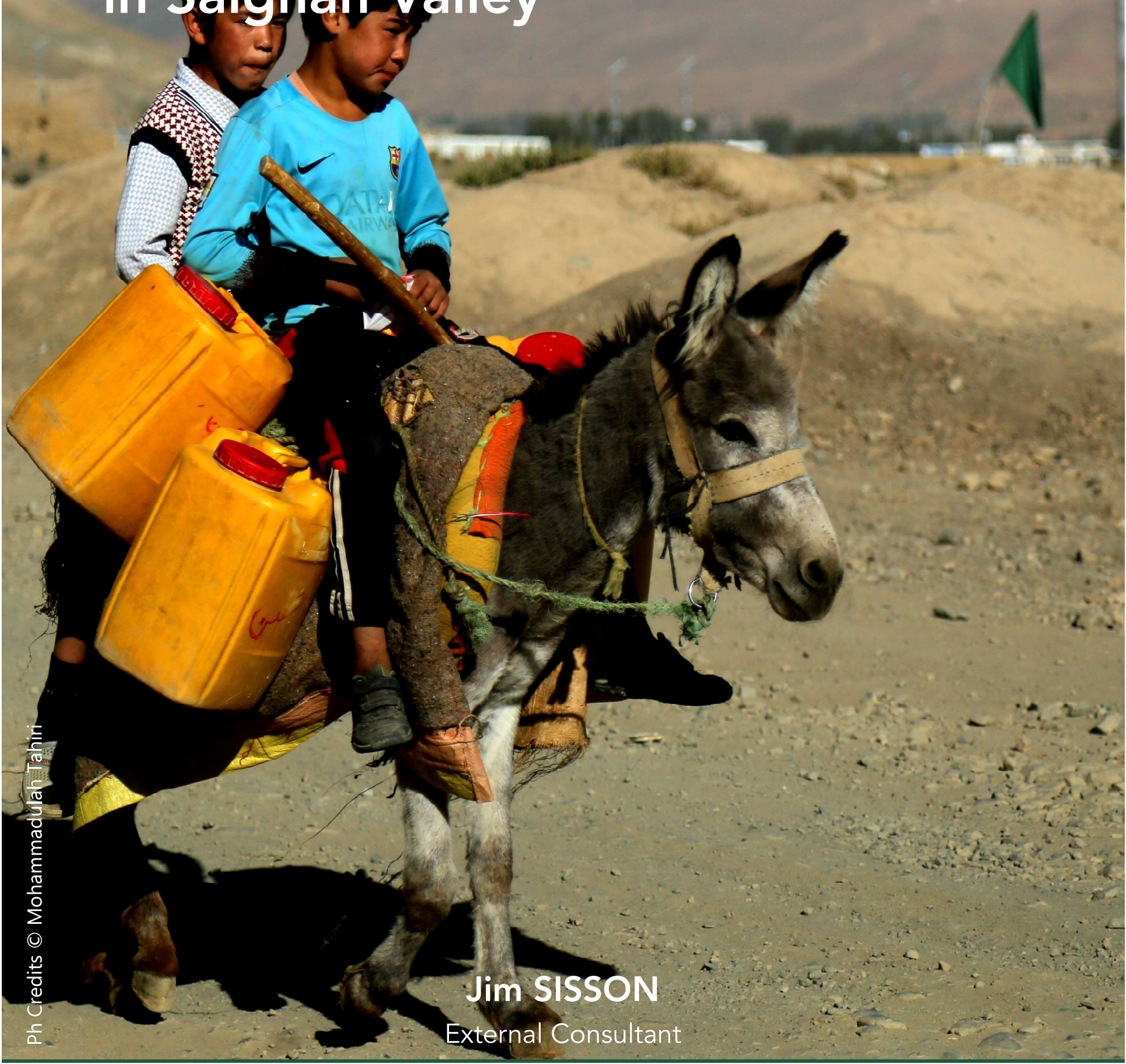

AFD

AGENCE FRANÇAISE DE DÉVELOPPEMENT
$\Delta$ central Highlands

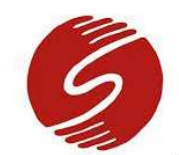

SOLIDARITÉS

INTERNATIONAL 


\section{AFD Mighlands \\ Sustainable Development Programme}

Central Highlands Programme (CHP) is common initiative implemented by a consortium of three French NGOs (GERES, MADERA and SOLIDARITES INTERNATIONAL) funder by the Agency for French Development (AFD). The general objective of the programme is to increase the living standards and quality of life of rural mountainous populations by promoting balanced rural development and preservation of natural resources. The 3.5 years programme was launched in March 2014 in two provinces of the Central Afghanistan: Bamyan and Maydan-Wardak.

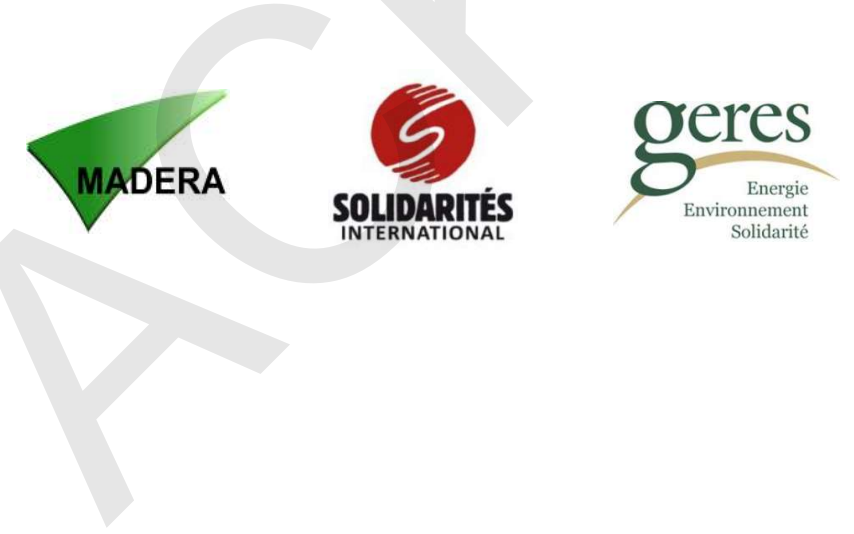

\section{(C) 2017 The Delegation to the European Union, Kabul, Afghanistan.}

This report was prepared by independent consultants contracted by implementing partners on behalf of The Delegation to the European Union. The views and opinions in this report do not necessarily reflect the views and options of The Delegation to the European Union or the implementing partner. 


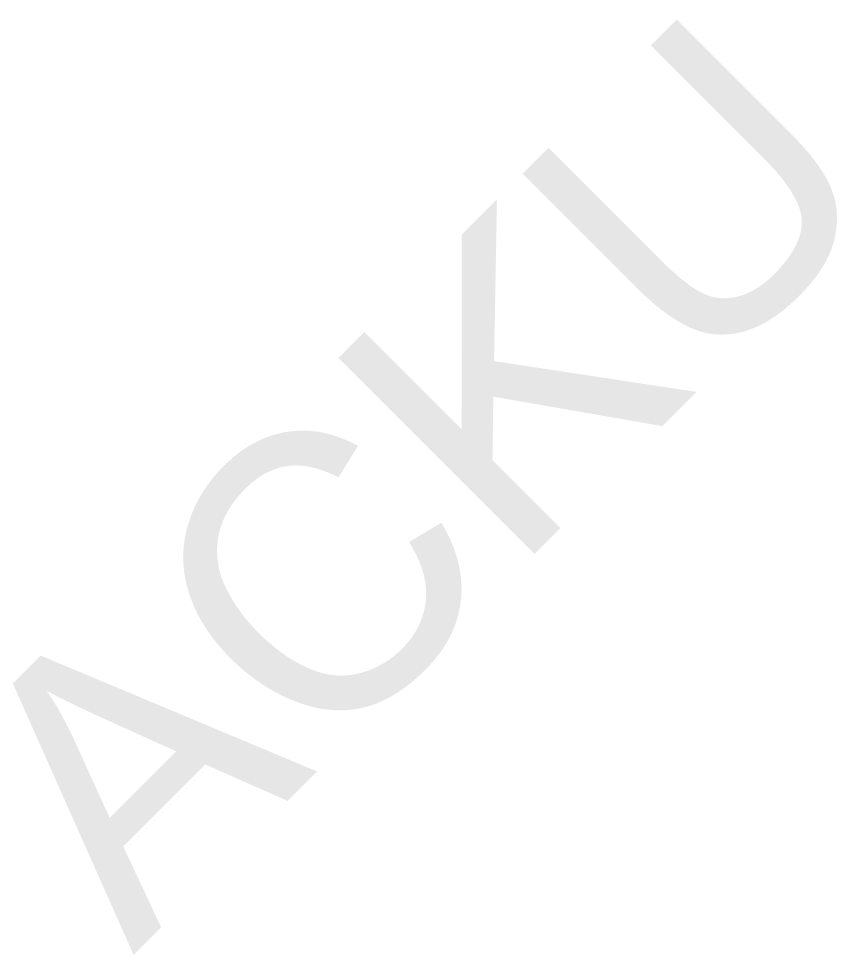




\section{Acknowledgements}

This consultancy was made possible by the assistance given by the Solidarités team at Saighan. In particular Shah Mamood, Zekrullah, Yaqub, Ezatullah, Nabi, Jaffar, Mohomadullah, and Abdul Gyas were all particularly helpful.

I am also indebted to Fernand Dhondt the Field Co-ordinator/Programme Manager who was always available and willing to offer assistance and advice. 


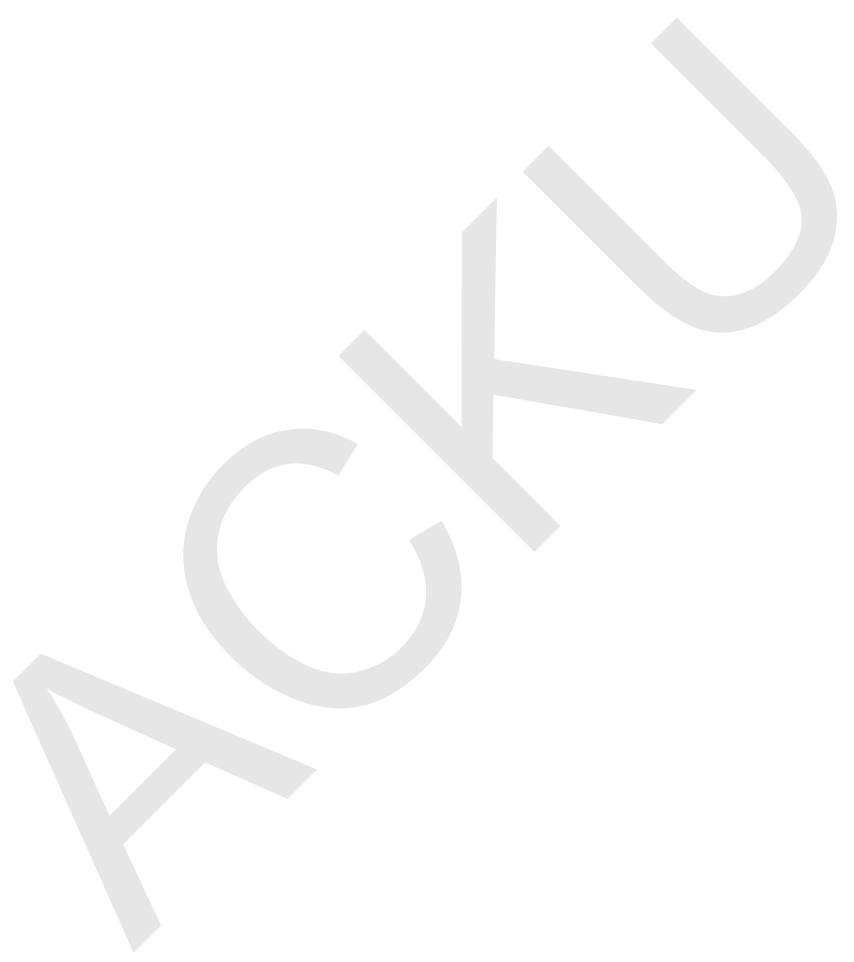




\section{EXECUTIVE SUMMARY AND SUMMARY OF MAIN RECOMMENDATIONS}

While this report covers many different aspects of water management in the Saighan Valley, the main focus has been on the means by which the communities along the Saighan River manage the water resource in a manner which is both efficient and sustainable. The Saighan Valley is noted for the lack of sufficient water resources to carry on agricultural activities in an effective manner. This has not always been the case as there is much anecdotal evidence that in the first seven decades of the last century the population size, amount of arable soil and the available water resource were in balance. However, since 1980 the population has increased significantly and as a result, the land use of much of the land has been changed from rain-fed low intensity agriculture to intensely cropped land. Consequently, the existing water resources have been found to be insufficient for carrying on irrigated agriculture on an increased area of cereal cropping land using the same water extravagant methods as had been found adequate in the past.

There are four main ways in which irrigated agriculture can be carried on in the valley in a more sustainable manner. The first of these is the obvious one of increasing the amount of available water by improving physical infrastructure. Secondly, if farmers could identify high value crops with lower water requirements, and find markets for them they could concentrate on those cash crops with a resultant reduction in water demand. Thirdly, the use of different agronomic methods by farmers to improve the water utilisation of crops would reduce the demand for water. And finally, the social water management of the existing resource which is the focus of this report could be improved to ensure more equitable management.

A matrix summarising each of these options in terms of the strengths and weaknesses is included at the end of this section.

Alone, the improvement of infrastructure including the development of sources such as ground water, whilst desirable, will not solve the problem of water shortage. The Saighan valley will always be short of water and regardless of what increases are made to the amount of water available, there will always be seasonal dry periods and occasional droughts. However, there is scope for increasing the water available for irrigation by developing the two (possibly three) natural reservoirs. These storages created by landslides, along with another man-made storage, have a combined capacity (estimated) sufficient to irrigate around an additional 2400 jerib $^{1}$ of wheat. Another suggestion has been to construct a kareez system which would supplement the existing water supply.

Both of these infrastructure developments would require substantial investment as the dams are merely water storages and do not have any of the necessary features to enable full exploitation of the stored water. The viability of a kareez has not been demonstrated, and before any commitment to construct one, a feasibility study would have to be carried out. This study has not addressed either of these options in depth as the writer is not sufficiently versed in many of the technical aspects involved.

There is scope for improving the existing physical assets such as repairing canals and canal intakes, but this should be approached in a strategic manner rather than the piecemeal approach currently being used with various actors all making what seem to be random interventions. Such work will only be fully effective if the additional water made available is applied to the crops in a more efficient manner through improved water management.

The replacement of the present cereal cropping with high value cash crops is a change which Solidarités regards as desirable and they are working at demonstrating the various possibilities. However, marketing infrastructure in the valley is in its infancy, and much additional works will have

\footnotetext{
${ }^{1}$ The jerib is the traditional measurement of land area in Afghanistan. One jerib is $2000 \mathrm{~m}^{2}$ in area and there are five jerib in one hectare
} 
to be carried out to encourage entrepreneurs to become involved on a larger scale in the marketing of products such as vegetables, fruit, and saffron.

At the moment most water is applied to the fields by flood irrigation, with the timing of watering determined by both tradition and water availability. There is much scope for improvement in water use efficiency by matching the time of application with the stage of plant growth, as well as aspects such as land preparation and methods of irrigation. Solidarités is working on changing both the types of crops grown and method of water application.

As stated above, the primary purpose of the study was to investigate the way in which both the village communities and the valley community managed the water resource. It was concluded that while the resource available was generally well managed by each individual community, there has been no attempt to manage the resource on a valley (or catchment) basis. Taking each village in isolation, farmers are generally satisfied with the manner in which water is distributed. Farmers from "water rich" villages are not concerned that they might be using water inefficiently. They are either oblivious to the fact that the agronomic methods they employ are at the expense of farmers from "water poor" areas, or they using their "position of power" as an opportunity to offset past political and social differences. It should be noted that the boundary between the "water rich" communities drawing water directly from the Saighan River, and the areas along the Saighan River with "water problems", coincides with the Hazara/Tadjik boundary. However this is not the case with the tributaries where communities of the same ethnic origin also are very unsympathetic to the water needs of each other.

The only solution to this impasse is to introduce a valley wide water management system whereby each community irrigation area is allocated a specific proportion of the available water. This will present substantial challenges and will require implementation of the relevant sections of the Water Act 2009 . When such a management system is being designed and implemented, consideration will have to be given to aspects such imposing a cap on the amount of land irrigated, particularly in the lowest sections of the valley, and possibly introducing a system where "water rights" can be transferred between land ownership titles. However, these concepts would be very new to Afghanistan and would require much study before their introduction.

\begin{tabular}{|c|c|c|c|}
\hline \multicolumn{2}{|r|}{ Recommendation } & \multirow[t]{2}{*}{ Priority } & \multirow[t]{2}{*}{ Responsiblility } \\
\hline No. & Summary & & \\
\hline \multicolumn{2}{|r|}{ Infrastructure } & & \\
\hline 2. & $\begin{array}{l}\text { Engineering and Economic feasibility study of developing two existing } \\
\text { dams for irrigation supply }\end{array}$ & High & $\begin{array}{l}\text { Solidarités/ } \\
\text { Europeaid }\end{array}$ \\
\hline 4. & $\begin{array}{l}\text { Thorough investigation of technical feasibility of all proposed well sites } \\
\text { before construction commences }\end{array}$ & Moderate & District Governor \\
\hline 5. & Education program on location of in-stream protection walls & Low & WMD \\
\hline 9. & Construct hose pipe demonstration & Moderate & $\begin{array}{l}\text { Solidarités/ } \\
\text { Europeaid }\end{array}$ \\
\hline 11. & Develop Scilly spring for domestic water supply & Moderate & $\begin{array}{c}\text { Solidarités/ } \\
\text { Europeaid }\end{array}$ \\
\hline 21. & Compile a comprehensive data base for all existing infrastructure & High & \\
\hline 24. & Lining of the Maidanak head ditch & Moderate & $\begin{array}{c}\text { Solidarités/ } \\
\text { Europeaid }\end{array}$ \\
\hline 25. & Investigate the viability of drainage water logged areas & Low & $\begin{array}{c}\text { Solidarités/ } \\
\text { Europeaid }\end{array}$ \\
\hline
\end{tabular}




\begin{tabular}{|c|c|c|c|}
\hline \multicolumn{2}{|r|}{ General } & \multirow[b]{2}{*}{ High } & \\
\hline 1. & $\begin{array}{l}\text { All parties to recognise that Saighan Valley environment is and always will } \\
\text { be dry and that agricultural development should take this into account. }\end{array}$ & & \\
\hline 10. & $\begin{array}{l}\text { All parties to note that the construction of dual purpose (irrigation and } \\
\text { domestic) water supply systems will only cause future problems. }\end{array}$ & Low & \\
\hline 20. & Efforts to be made to include RRD SOs in water management activities & Moderate & $\begin{array}{l}\text { Solidarités/ } \\
\text { Europeaid/RRD }\end{array}$ \\
\hline \multicolumn{4}{|c|}{ Agronomic } \\
\hline 7. & Demonstration and extension work to continue in crop management & High & $\begin{array}{c}\text { Solidarités/ } \\
\text { Europeaid }\end{array}$ \\
\hline 8. & $\begin{array}{l}\text { Demonstrations to be established to show more water use efficient } \\
\text { methods of irrigation using conventional means }\end{array}$ & High & $\begin{array}{l}\text { Solidarités/ } \\
\text { Europeaid }\end{array}$ \\
\hline 12 & Demonstration of use of flexi flume in horticultural situation & Moderate & $\begin{array}{c}\text { Solidarités/ } \\
\text { Europeaid }\end{array}$ \\
\hline 14 & $\begin{array}{l}\text { Introduce high value crops and encourage movement away from } \\
\text { subsistence farming }\end{array}$ & High & $\begin{array}{l}\text { Solidarités/ } \\
\text { Europeaid/CARD-F }\end{array}$ \\
\hline \multicolumn{4}{|c|}{ Social Water Management } \\
\hline 3. & $\begin{array}{l}\text { Agreement between recipient villages on the social management of all } \\
\text { future wells }\end{array}$ & Moderate & \\
\hline 6. & Develop a strategic plan for all future water resource development & High & PARBP/WMD \\
\hline 13. & $\begin{array}{l}\text { Consult with relevant communities before finalising the location of future } \\
\text { mHEP plants }\end{array}$ & Moderate & PARBP/WMD \\
\hline 15. & Ensure that all farmers have a say in the way water is managed & High & PARBP \\
\hline 16. & Encourage CDCs to appoint interim sub committees responsible for SWM & Low & District Governor \\
\hline 17. & $\begin{array}{l}\text { Where appropriate retain and integrate the Mirab system into a } \\
\text { catchment management system }\end{array}$ & Moderate & PARBP \\
\hline 18. & $\begin{array}{l}\text { Design and implement a training system for Mirabs initially focussing on } \\
\text { measurement of water discharge }\end{array}$ & Moderate & $\begin{array}{l}\text { Solidarités/ } \\
\text { Europeaid/PARBP }\end{array}$ \\
\hline 19. & Brief the DDA on SWM & Low & $\begin{array}{c}\text { Solidarités/ } \\
\text { Europeaid }\end{array}$ \\
\hline 22. & $\begin{array}{l}\text { Give all possible assistance to the PARBP when it commences operations } \\
\text { in the Saighan Valley }\end{array}$ & High & $\begin{array}{c}\text { Solidarités/ } \\
\text { Europeaid/district } \\
\text { Governor }\end{array}$ \\
\hline 23. & $\begin{array}{l}\text { Locate a copy of the "Qarawna Dam Agreement" documents and assess } \\
\text { them for suitability as a model for other situations }\end{array}$ & Moderate & $\begin{array}{l}\text { Solidarités/ } \\
\text { Europeaid }\end{array}$ \\
\hline 26. & $\begin{array}{l}\text { Locate and assess the "Daud era" documents and assess their relevance } \\
\text { to the present situation. }\end{array}$ & High & PARBP \\
\hline 27. & Introduce a catchment wide SWM framework for the Saighan Valley & High & PARBP \\
\hline
\end{tabular}




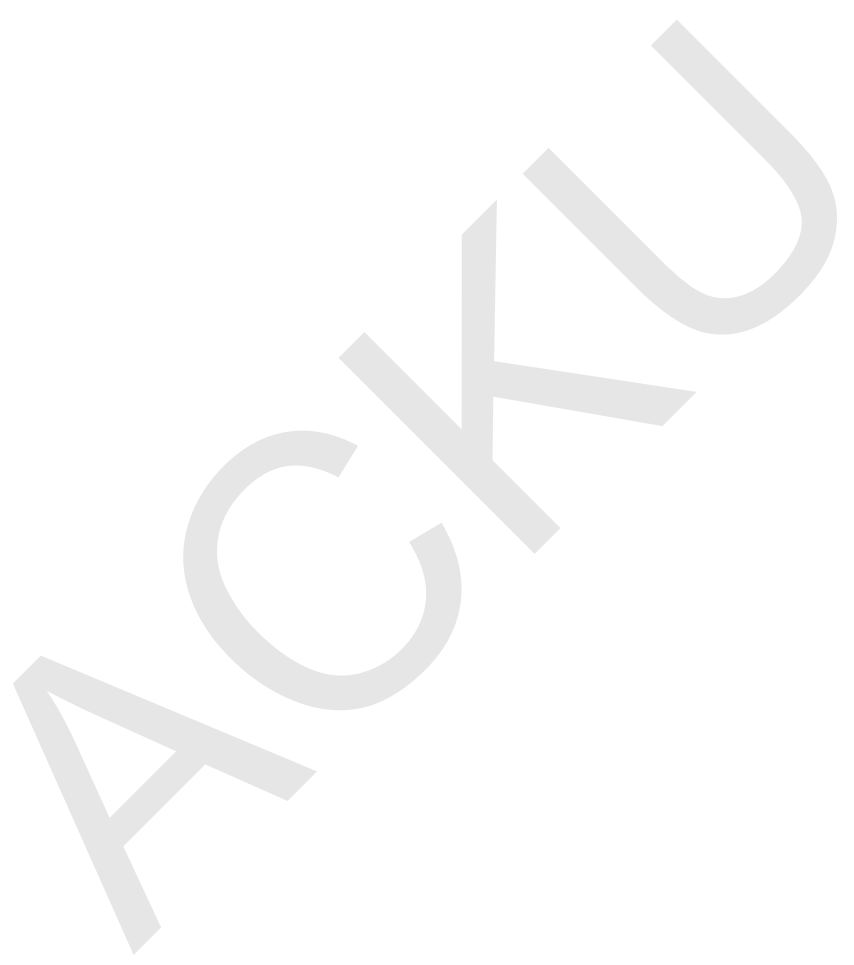




\section{Contents}

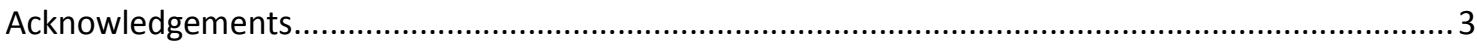

EXECUTIVE SUMMARY AND SUMMARY OF MAIN RECOMMENDATIONS ....................................... 5

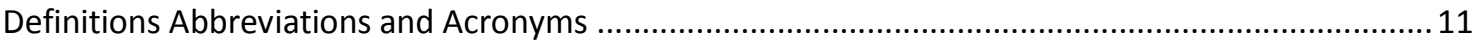

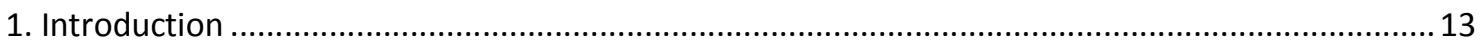

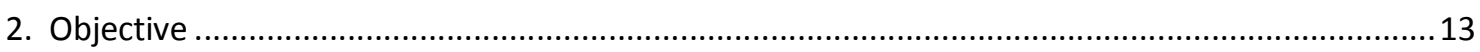

3. History of Water Management in the Saighan Valley...............................................................13

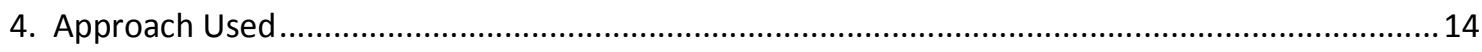

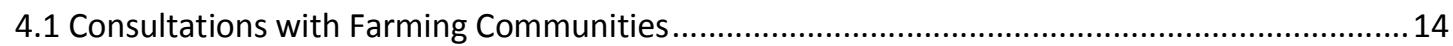

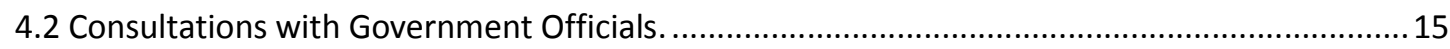

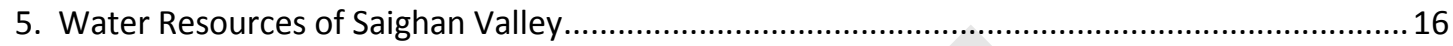

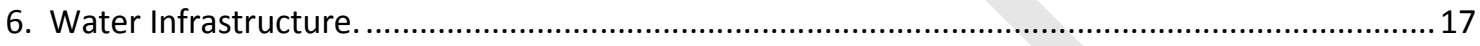

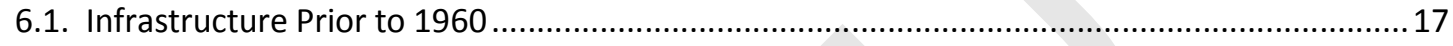

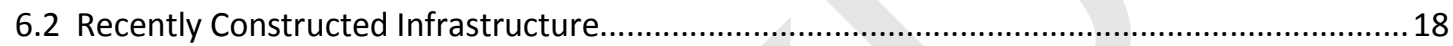

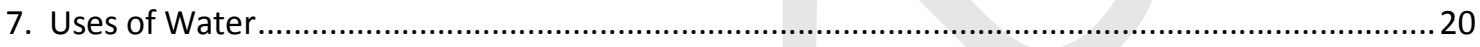

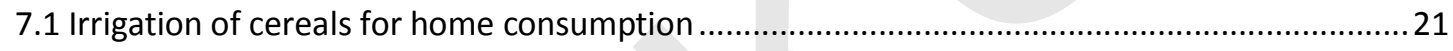

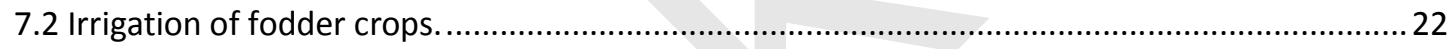

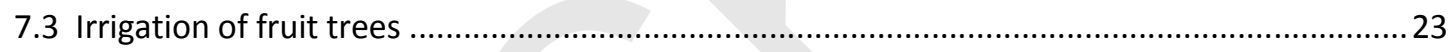

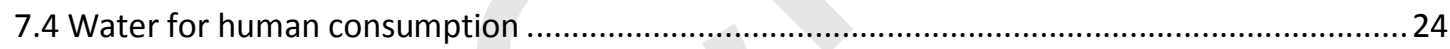

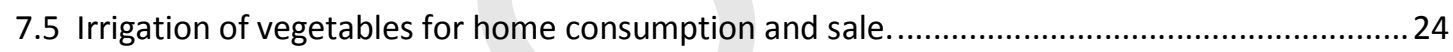

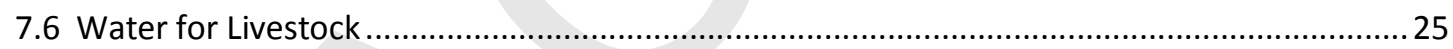

7.7 Water for generating electric power and milling grain. .......................................................25

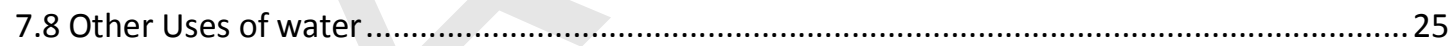

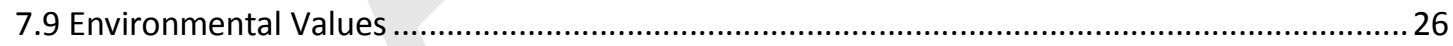

8. Stakeholders in the Management of the Water Resource. ...........................................................26

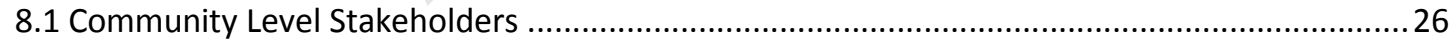

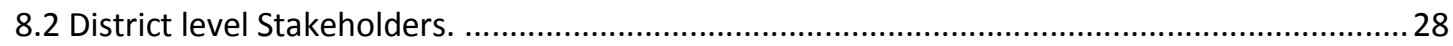

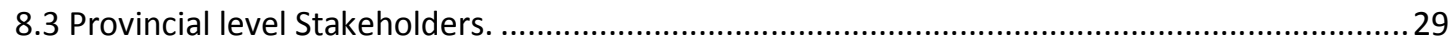

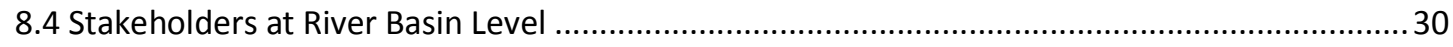

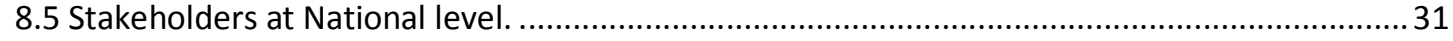

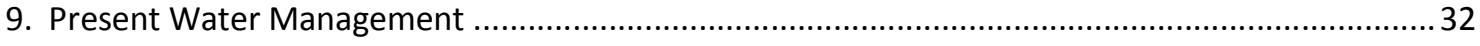

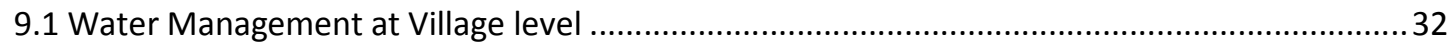

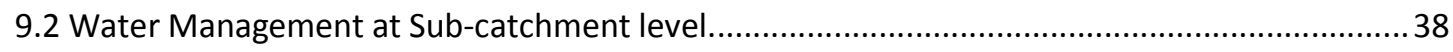

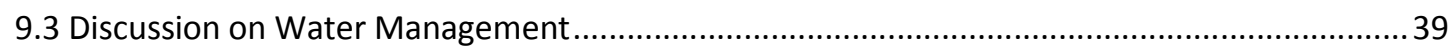

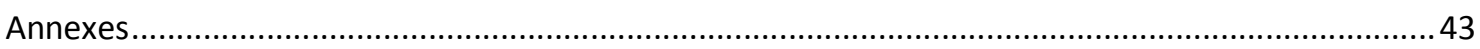




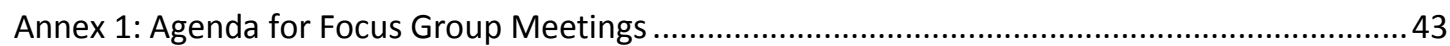

Annex 2: Site Inspection Report - Korsum and Doume Jangal Dams................................................ 44

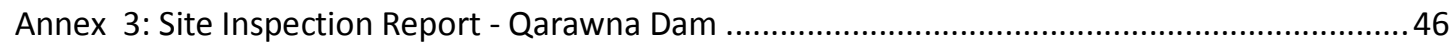

Annex 5: Efficient Water Use in Cropping - Some Ideas .............................................................. 51

Annex 6: Water User Associations and River Basin Management......................................................53

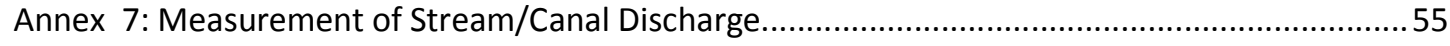

Annex 8: Terms of Reference for the Water Resource Specialist ......................................................56 


\section{Definitions Abbreviations and Acronyms}

\begin{tabular}{|c|c|}
\hline Afs & Afghani unit of currency $1 \mathrm{Af}=\$ 0.02$ (approx) \\
\hline AHDP & Animal Health and Production Project (funded by the European Commission) \\
\hline ARBP & Amu River Basin Project \\
\hline CA & Command area \\
\hline CARD -F & Comprehensive Agriculture and Rural Development Facility \\
\hline CCDC & Cluster Community Development Council \\
\hline CDC & Community Development Council \\
\hline Seer & Unit of measurement usually applied to crop yield. 1 seer $=7 \mathrm{~kg}$. \\
\hline couc & An Afghani NGO \\
\hline DDA & District Development Assembly \\
\hline DDP & District Development Plan \\
\hline DG & District Governor \\
\hline $\mathrm{D} / \mathrm{S}$ & Downstream \\
\hline FGM & Focus group Meeting \\
\hline FSL & Full supply level \\
\hline GE & Google Earth \\
\hline Gazak & Upland area in the mountain area of Afghanistan \\
\hline ICARDA & International Center for Agricultural Research in the Dry Areas \\
\hline KRBP & Kunduz River Basin Project \\
\hline LRRD & $\begin{array}{l}\text { Linking Relief to Rehabilitation and Development through Food Security } \\
\text { Interventions in Areas Affected by Natural Disasters and Prolonged Insecurity in } \\
\text { Afghanistan }\end{array}$ \\
\hline I/sec. & Unit of flow. Litres/sec. \\
\hline Lucerne & Sometimes called alfalfa \\
\hline MAIL & Ministry of Agriculture Irrigation and Livestock \\
\hline MEW & Ministry of Energy and Water \\
\hline mHEP & Micro Hydro Electricity Power plant \\
\hline ML & Megaliter. $1 \mathrm{ML}=1$ million litre \\
\hline $\mathrm{mM} 3$ & Million cubic meters \\
\hline MRRD & Ministry of Rural Rehabilitation and Development \\
\hline NA & Not Applicable \\
\hline
\end{tabular}




\begin{tabular}{ll} 
NRVA & National Risk and Vulnerability Assessment \\
NABDP & National Area Based Development Program \\
NGO & Non government organisation \\
NSP & National Solidarity Program \\
PARBP & Panj Amu River Basin Program \\
PM & Project Manager \\
PRT & Provincial Reconstruction Team \\
RRA & Rapid Rural Appraisal \\
SO. & Social Organiser \\
SV & Saighan Valley \\
SWM & Social Water Management \\
ToR & Terms of Reference \\
UNAMA & United Nations Assistance Mission to Afghanistan \\
UNHABITAT & United Nations Human Settlement Programme \\
U/S & Upstream \\
WASH & Water and Sanitation, Hygiene \\
WMD & Water Management Department \\
\hline
\end{tabular}




\section{Introduction}

In 2009, Solidarités started implementing the LRRD which has the objective of linking emergency and development activities in the Saighan Valley. One of the four main axes is improving access to irrigation water, and in the initial planning it was proposed that this could be achieved through digging wells and equipping them with pumps. Together with the proposed construction of a kareez (or a number of kareez), it was envisaged that the irrigation area could be increased by 200 ha.

The Social Water Management consultancy was originally intended to take place after an initial study of the physical water resource, but it became expedient to reverse the order of inputs and the SWM study preceded the water resource study.

The recently completed SWM study was not able to identify an area of 200 ha where access to irrigation water could be improved, but it was able to identify possible methods of improving management of the resource which would on aggregate increase production by an equivalent of 200 ha.

\section{Objective}

The objective of the Social Water Management study is to:

To provide a better understanding of the social water management in the Saighan District.

- $\quad$ To identify the different uses of water

- To characterize the stakeholders involved in this management and their relationships.

- To identify and localize the main problems/issues linked to this management (conflicts, lack of water...)

- To give some relevant recommendations in order to draft some activities to support good practices in terms of Water management.

This should also lead to a re-definition of the initially predicted activities for LRRD project in term of water access for irrigation. The result to be reached is "Yields are secured in drought affected areas" which correspond to the better irrigation of 200 ha of irrigated land.

\section{History of Water Management in the Saighan Valley}

It is not known how long irrigated agriculture has been conducted in the Hazarajat, but it would be measured in thousands of years. During this time, the community based Mirab system evolved. This Mirab or "Water Master" system has persisted in some form in most Saighan District villages until the present time, with the exception of a period during the mid to late 1970s when the government intervened and imposed a state sponsored water management regime.

This intervention was introduced during the office term of President Daud (1973-78). As far as Saighan Valley was concerned, the main impact was the introduction of a river basin approach. This involved the delineation of "zones", the boundaries of which were determined by perceived access to irrigation water supply. The system resulted in a reasonably equitable distribution of water. The management system provided for various records to be kept including agreed water allocations throughout the (sub) catchment, and was regarded as being an appropriate means of water management particularly by the communities which suffered the most severe water shortages.

In Saighan Valley, the function of Mirab was performed by government appointed officials who ensured that water allocations were delivered to each community. After the fall of the Daud regime, the river basin approach went into decline and with the increasing disorder completely lapsed by the 1980s. 
In Saighan Valley, the Mirab system is still retained in various forms. Some villages maintained the traditional Mirab system while others opted for variations of it. Many institutions have been involved in the design and construction of infrastructure but, apart from the village communities themselves, the only known interventions carried out in the field of social water management have been by the District Governor's office and the Provincial Water Management Department, who have both become involved in water management issues in an ad hoc manner. There have never been any state sponsored irrigation schemes.

\section{Approach Used}

The consultancy was carried out over a period of six weeks of which five weeks were spent in the field in Saighan District. This time in the field was spent reviewing project documents including the LRRD Proposal document, consulting with various stakeholders, conducting Focus Group meetings with communities, carrying out site inspections at various locations, and mapping relevant catchment features.

\subsection{Consultations with Farming Communities}

To obtain data from the communities, a sample of villages was selected after consultation with the Solidarités Field staff. These villages were as follows.

Table 1

\begin{tabular}{|l|c|c|c|l|}
\hline Name of Community & \multicolumn{2}{|c|}{$\begin{array}{c}\text { No. of } \\
\text { families }\end{array}$} & $\begin{array}{c}\text { Approx area of } \\
\text { irrigated land } \\
\text { (jerib) }\end{array}$ & \multicolumn{1}{|c|}{$\begin{array}{c}\text { Main Source of water for } \\
\text { Irrigation }\end{array}$} \\
\hline & $(1)$ & $(2)$ & $(3)$ & \multicolumn{1}{|c|}{$(4)$} \\
\hline Khudadad Khil/Baghi Miran & 266 & 266 & 350 & $\begin{array}{l}\text { Qarawna stream and Saighan } \\
\text { River }\end{array}$ \\
\hline Darwishan & $?$ & 89 & 480 & Sukhta Chenar stream \\
\hline Sukhta Chenar & 89 & 70 & 2000 & Sukhta Chenar stream \\
\hline Qarawna & 362 & 528 & 1100 & Qarawna stream \\
\hline Qarakhawal & 116 & 125 & 300 & Saighan River \\
\hline Bayan Qoli & 500 & 315 & 1600 & $\begin{array}{l}\text { Saighan River, Charagh Dan } \\
\text { stream }\end{array}$ \\
\hline Deh Nula/Nowabad/Khudadad Khil & 275 & 205 & 3500 & $\begin{array}{l}\text { Saighan River and Qarawna } \\
\text { stream }\end{array}$ \\
\hline Sar-e-Tang & 218 & 218 & 500 & Saighan River \\
\hline Sumucha/Deh Aman/Said Baba & 370 & 660 & 2300 & Saighan River \\
\hline Maidanak (5) & $?$ & 200 & 200 & High mountain spring \\
\hline
\end{tabular}

Notes

(1) Number as families as contained in data held at Saighan Solidarités Office, source unknown.

(2) Number of families as reported by community representatives at the meetings

(3) Total area irrigated as reported at meetings. 
(4) The names of the water courses include some which have been allocated by the writer as each community seems to know the particular water course by a different name.

(5) This meeting was not a true focus group. When the opportunity presented itself, a lengthy interview and site inspection of the location was conducted with a single farmer. Maidanak is actually an area farmed by part of Said Baba community.

Meetings were scheduled for each location with each community being asked to send a representative sample of no more than 15 farmers, including farmers from each reach of the canal/water course, a CDC member, and some poor or landless farmers.

Each meeting lasted between two and three hours. The meetings were conducted solely to collect information and the meeting agenda is attached as Annex 1.

\subsection{Consultations with Government Officials.}

Separate consultations were held with officials from both District and Provincial levels.

These are summarized as follows:

\begin{tabular}{|l|l|l|l|}
\hline \multicolumn{1}{|c|}{ Institution } & \multicolumn{1}{|c|}{ Date } & \multicolumn{1}{c|}{ Person } & \multicolumn{1}{c|}{ Outcome } \\
\hline UNHabitat & $24 / 3,18 / 4$ & Abdul Wardud & List of all UNHabitats water related activities \\
\hline $\begin{array}{l}\text { District Govrs } \\
\text { Office }\end{array}$ & $28 / 3$ & Govr. Saighani & Description of water related issues \\
\hline Prov. RRD & $30 / 3,31 / 3$ & Dir. Basir & Overview of situation in Saighan District \\
\hline Prov. WMD & $30 / 3$ & D/D (Finance) & Overview of situation in Saighan District \\
\hline & $24 / 4$ & Dir. Hamid & Overview of situation in Saighan District \\
\hline Prov. MAIL & $31 / 3$ & Head Admin & No significant outcome \\
\hline & $25 / 4$ & Dir. Tahi & Overview of situation in Saighan District \\
\hline RRD (District) & $5 / 4$ & $\begin{array}{l}\text { SO's Supon and } \\
\text { Ramon }\end{array}$ & Overview of situation in Saighan District \\
\hline DDA & This meeting was scheduled for 7/4 but was cancelled by the DG \\
\hline EuropeAid & $26 / 4$ & $\begin{array}{l}\text { C Hell and E } \\
\text { Faubert }\end{array}$ & Briefing on progress to date \\
\hline
\end{tabular}

A workshop to confirm the information collected was conducted on April $22^{\text {nd }}$ at the end of the field work in Saighan, and a workshop/brain storming session was held on April $24^{\text {th }}$ with Solidarités field staff. Final consultations were held at National level in Kabul.

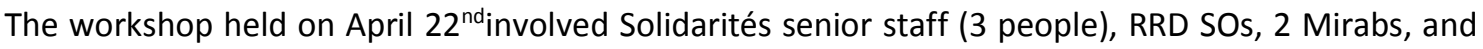
approximately 6 village leaders from the various parts of the catchment, and the brainstorming session involved all Solidarités Saighan based staff.

\footnotetext{
${ }^{2}$ The MRRD employs Social Organisers (SOs) based at District level in most Districts of the country.
} 


\section{Water Resources of Saighan Valley}

The only available rainfall figures for Afghanistan are for Kabul which has an annual average rainfall of $316 \mathrm{~mm}^{3}$, most of which occurs between the months of February and May. In the Saighan Valley case, this rainfall is supplemented by runoff due to snow melt which provides a substantial proportion of the surface runoff from April to June.

There are no stream gauging data for the Saighan River or its tributaries. However, observed stream flows during the brief period of observation exhibited both spatial and temporal variations when two separate high intensity rainfall events in April resulted in flash flooding along the Saighan Valley. Both of these events resulted in very steep hydrographs with the resultant flooding causing damage.

Sub-surface waterflows occur along the whole length of the Saighan River with discharge and recharge at many different points. Some reaches of very permeable material in the stream bed cause rapid infiltration, while in others, springs discharge back into the stream. Thus at any time the stream can comprise reaches of flow downstream of others where there is none, and conversely reaches of noflow downstream from reaches of flow. This can be exacerbated or negated by diversion of flows for irrigation.

Both drought and floods are frequent occurrences in the area. Although no rainfall data is available, local informants report that the two worst water shortage periods were in 2001-03 and 2007-08. In other years there are dry periods of varying length and severity. 
There are no records of spring yield but the writer estimated the following yields at various locations in the catchment:

\begin{tabular}{|l|l|c|}
\hline \multicolumn{1}{|c|}{ Name of Spring } & \multicolumn{1}{|c|}{ Location } & Estimated Yield (I/sec) \\
\hline Scilly & Sabez Qala & 3 \\
\hline Upstream from Scilly spring & Sabez Qala & $>10$ \\
\hline Doume Jangal & Tail water of Doume Jangal Dam & $>20$ \\
\hline Qarawna & Tail water of Qarawna Dam & $>20$ \\
\hline
\end{tabular}

The figures for the two dam-sites are estimates of the inflows into the dam and may not be entirely spring flow, but in the writers opinion most of these flows were from ground water discharge as there had been no significant runoff events for several weeks prior to the observations. Reports from the Maidanak area are that spring flows are $>30 \mathrm{l} / \mathrm{sec}$. throughout the year.

\section{Water Infrastructure.}

\subsection{Infrastructure Prior to 1960}

The water conservation and irrigation infrastructure in the valley was relatively undeveloped until quite recently. Prior to the accelerated development starting in the 1990s, most infrastructure work consisted of water intake structures built annually on the major streams, and earthen canals excavated to convey water from the intakes to the command area. The intakes were often little more than earthen levees constructed across the stream bed and reinforced with local materials such as branches and stones, and would have to be rebuilt each year because of flood damage. A limited number of in-stream concrete weirs were constructed on the Saighan River. Such structures were built in order to lift the stream bed to the level of the surrounding land so that stream flows could be diverted into canals. The location of these structures was determined by communities to fit land ownership patterns and to maximise the command areas.

Water specifically for human consumption came from hand dug wells located on the flood plain and sometimes in the river bed, spring cappings located to capture spring flows and (sometimes) associated primitive reticulation systems to take water to settlement areas. Water for human consumption was also obtained directly from both streams and canals.

Water driven flour mills were a feature of the valley until recent times. The number of these mills has declined markedly due to both the decreased flow levels needed to power them and the provision of motorised mills to some villages under the NSP.

There were no man-made structures to store runoff, and the only groundwater harvesting structures are wells. Kareez have never been constructed in the district.

In 1956 an earthquake and resulting landslides caused the formation of at least two artificial lakes high up in the catchment. Both of these lakes have persisted to the present and appear to be stable structures which are currently not exploited in any significant way for water conservation. ${ }^{6}$ There are reports of two more dams which were created in the same manner as the first two. None of these dams can be considered as infrastructure as they are not utilised for any significant purpose.

\footnotetext{
${ }^{6}$ Both Doume Jangal and Korsum dams have large capacities. For further details see the inspection reports (Annex 2)
} 


\subsection{Recently Constructed Infrastructure}

There have been many interventions by a range of institutions who have built water conservation and utilisation structures in the years since the end of the civil war in $1996 .^{7}$ Amongst many others, some of these interventions have been: 


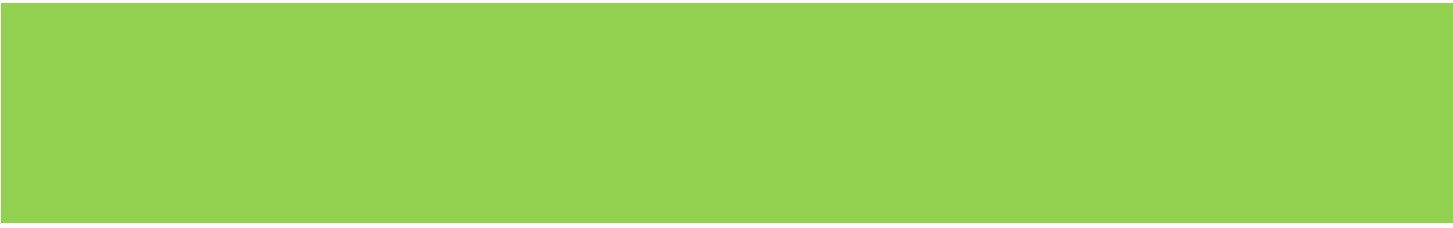


There are two known spring cappings in the valley, but it is likely that there are more. The known spring cappings are at Darwishan where the ICRC funded the works, and at Sukhta Chenar where Solidarités carried out the work in c 2007. 


\subsection{Irrigation of cereals for home consumption}

This water use was overwhelmingly declared as the most important. In the sample villages a total of 1630 ha was reported to be irrigated annually while 3312 ha is grown in the entire district. ${ }^{12}$ All communities carry out this activity and wheat is always given priority over other crops and uses when water is in short supply. Water is sourced from canals using gravity systems. No use of pumps was reported and the only known case where springs were used was at Maidanak and Pushtawaz ${ }^{13}$.

Both spring and winter wheat are sown with the latter being the most important. ${ }^{14}$ Varieties used are grouped into either "local varieties" or "improved varieties". Both of these terms are misnomers in that they both include hybrids which are neither one nor the other. The true "improved" varieties are those introduced in the last two years by organisations such as Solidarités, and which are then multiplied by specialised seed growers.

Between 3 and 6 water applications are made depending on water availability. These applications are estimated to be $25-40 \mathrm{~mm}$ each.

A range of watering strategy/seed variety/resultant yield data was presented at the different focus meetings. Some examples of this data are presented below:

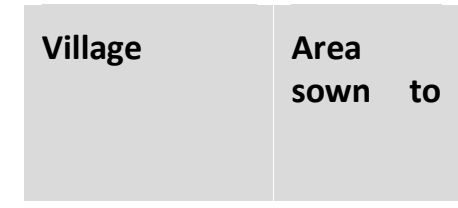


application rates at specific times during the crop's development. This latter water saving is being demonstrated on Solidarités research farms which have a soil structure typical of most irrigated soils in the valley. It has been estimated that up to $30 \%$ of the water currently applied to cereal crops could be saved if crops were sown several weeks later and if water was applied at much slower rates during three particular growth stages (bush, flower and milk stages). ${ }^{17}$

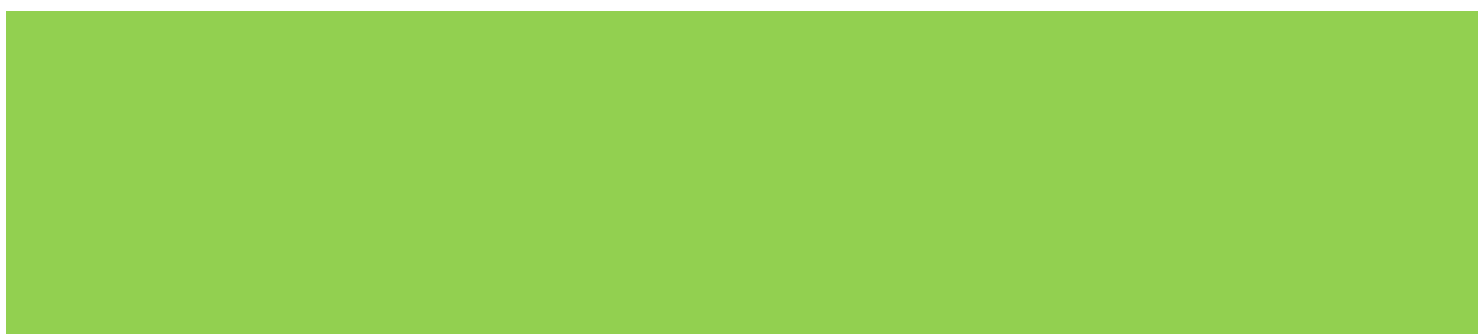


Lucerne stands can be cut 4 to 5 times per season in years 3 to 6 , but from then on the stand deteriorates and normally by year 8 it is replaced with the next wheat crop. A good stand will yield up to $1.5 \mathrm{t}$ of dry matter/jerib/cutting. Farmers store most of the material as hay and use it for winter feeding of their own livestock. If sold, it can bring up to Afs 15000/jerib/year.

Lucerne will respond to increased watering but the watering strategy varies according to water availability. At most, it will receive 3 dedicated waterings and in times of severe drought it will not be watered. Water is applied by flood using the same infrastructure as wheat. Ideally it should be watered once after sowing in September, again in November, and twice more in the April/May period. It can be grazed instead of cut, but normally the July growth is cut and conserved by drying it in windrows and then storing it.

Water is applied by flood irrigation and is applied at similar rates as wheat.

\subsection{Irrigation of fruit trees}

Apricots are the main cash crop followed by almonds and to a lesser extent, apples. Each are frequently undersown with clover thus requiring a differential watering strategy as clover swards require more frequent waterings. ${ }^{20}$ The fruit trees are watered by excavating furrows between trees and mounds around each tree. These ditches prevent the flood irrigation from contacting the tree stem and promoting fungal diseases.

All apricots are dried using a sulphur treatment and then sold to agents at the farm gate. These agents are either resident in the village or come from Mazar or Kabul to purchase the crop. While some of the crop is consumed at home the amount is insignificant. Annual returns to the grower in a good year can be as high as Afs 100,000/jerib, but frosts frequently cause crop failures with some areas not yielding commercial amounts for up to 10 years.

The most common variety of apricot tree is a "local" one which grows to a much greater height than the variety recently introduced. Frost damage during bud development is a major hindrance to the industry and there were no reports of anyone using watering strategy to reduce the damage done by frost in the months of March and April when buds are most susceptible. Most orchards are small with the average being in the vicinity of 1 jerib. This small orchard size and the scattered locations of the orchards make it difficult to introduce new technologies and more efficient orchard management methods.

In the 10 sample villages, it was estimated that a total of 1300 jerib were dedicated to fruit and nut growing. ${ }^{21}$ 


\subsection{Water for human consumption}

Domestic water is obtained from either springs (capped and uncapped), wells equipped with hand pumps, or canals and streams. Treatment such as boiling drinking water is rare with the only treatment being letting it stand in order to settle sediment. An average family of 7 uses an average of $25 \mathrm{l} /$ day for drinking and 10-15 I/person for washing.

In times of drought, some communities have to cart water from permanent springs up to $3 \mathrm{~km}$ away. In many instances these water sources are in other villages and taking water has to be done with the agreement of the Shura from the village which "owns" the spring.

Over the past 10 years a number of springs have been capped and protected from contamination. Such work has been done at Sukhta Chenar (Solidarités), and (reportedly) at Kareez Village by ICRC. There are other known springs where such work could be carried out.

Apart from wells, most domestic water is obtained directly from canals and rivers. Such sources are very prone to contamination as livestock have access to the same points. The incidence of water borne diseases is unknown but in 2009 Solidarités stated that there is an average of 4 cases of diarrhoea per family per month ${ }^{23}$. 


\subsection{Water for Livestock}

Water distribution from the canals and streams for the 20000 head of livestock in the District is not controlled. ${ }^{25}$ There are no dedicated access points and thus animals have free access to water which is used for domestic consumption. During the winter, housed animals have water carted to them and in summer animals, being grazed on the higher Gazak areas, obtain water from springs and soaks. There are many local reports of livestock having perished for lack of water during the severe drought of 2008, but these have not been substantiated as entirely due to water alone as lack of feed must have also been a factor.

\subsection{Water for generating electric power and milling grain.}

Ten mini HEP stations have been constructed in recent years. These are located predominantly in the upper sections of the valley with the lowest being at Deh Nula/Nowabad. Every one of them uses water from the river with none located on the tributaries. The amount of water available is seasonal and determines the length of time the stations operate. When there are sufficient flows, the stations will operate at night with power being used for lighting. In the upper reaches power is generated for up to 5 months during the November to March period, while the lowest station operates during the two winter months when flows are high and water requirement for other uses is low.

Water is directed to the station by either specially constructed canals or canals constructed primarily for irrigation. The discharge from the stations is often back to the river which concerns the local community as it then becomes unavailable for irrigation in that village. ${ }^{26}$

In previous periods there were up to 40 operating flour mills in the valley compared with the present $10 .{ }^{27}$ The reasons for this reduction are the reduced motive power and the introduction of motor driven mills under the NSP. The mills still operating are generally located adjacent to the HEP stations.

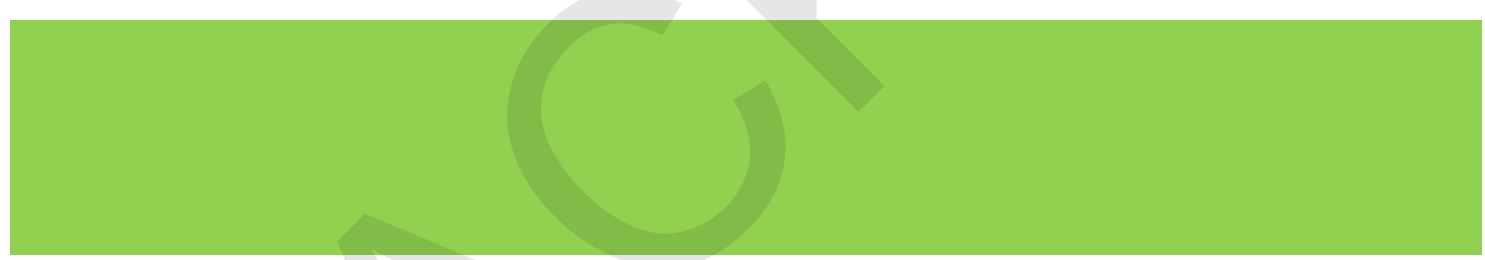




\subsection{Environmental Values}

No community member or government official mentioned the fact that water resources are an essential part of the environment, nor did they appear to have any understanding of the concept. It is included in Table 4 to illustrate this point.

\section{Stakeholders in the Management of the Water Resource.}

\subsection{Community Level Stakeholders}

Almost all families in the valley are engaged in farming and those that do not own or work land, are directly affected by the access to the district's water sources. All farmers are involved in irrigated agriculture which is the predominant agricultural activity. As individuals, farmers have little impact on water management. 


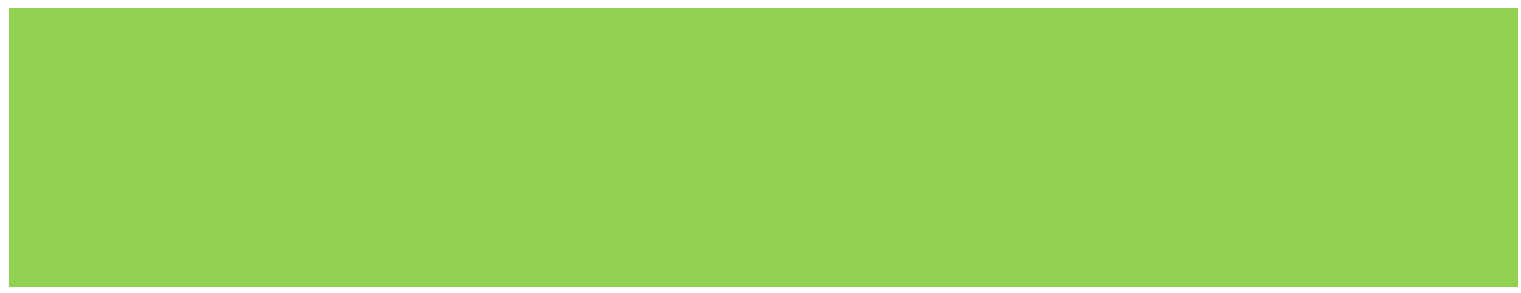




\subsection{District level Stakeholders.}

There are two main stakeholders at this level. These are the District Governor and his staff, and the District Development Assembly.

The District Governor (DG) becomes involved in resolving issues on an ad hoc basis and does not have any policy guidelines apart from traditional practice and pragmatism. In most cases he is the final authority on inter-village disputes and only becomes involved when requested. He is also the first point of contact when outside institutions become involved in any water resource related issue, and he takes the lead in issues such as lobbying for the construction of kareez.

The Saighan District Development Assembly (DDA) is the community based organisation which is tasked with developing a strategic District Development Plan (DDP) ${ }^{30}$. It comprises CDC members usually elected via a second tier referred to as CDC Clusters (CDCCS). In Saighan the CDCs are grouped together into 7 clusters, with each CDC appointing two of its members to the relevant cluster. Each cluster then appoints two members to the DDA. Thus the DDA will comprise 14 members who are representative of the general community. To date the only known water related activity of the Saighan DDA is the development of a District Development Plan which listed the "construction of new and restoration of existing irrigation systems" as a major objective. Despite several attempts the consultant was unable to interview the DDA. The DDA plays no known direct role in water management. 
fertiliser distribution. To date they have not been particularly successful. ${ }^{34}$ The initial establishment is carried out by the provincial office and once established, they are supported by District staff. ${ }^{35}$

UNHabitat which presently employs five engineers in the district has been very active in implementing works programs involving upgrading water utilisation infrastructure. Between 2003 and 2009 they have constructed 16 new irrigation canals, at Bayon Qoli, Sar-e Tang, Sukhta Chenar, Qarawna, Qarakhawal, Said Baba, Charagh Dan, Qurghan, Dohne Sarayak, Doume Jangal, and Erganak. ${ }^{36}$ They have also constructed micro HEP plants at Said Baba, Deh Nula and Qarawna, and 51 wells at Karez, Airghana Chacha, Qala Bigale, Amrout, Bayon Qoli, and Said Baba. ${ }^{37}$

All works undertaken by UNhabitat are determined at national level with the works program passed to the district office via the Provincial Manager. It is not known how the works are prioritised. Their responsibility ends when the works have been completed and they do not conduct any training on the subsequent management of the works. ${ }^{38}$

Other known institutions which have been involved in water resource development are Solidarités (dam, canal and intake construction), COUK (canal and well construction), PRT (mHEP station construction), the Bayaani Foundation (wells) and JICA (funding for canals and mHEP).

The only known farmer organisations carrying out activities in the Saighan valley are the co-operatives established by Provincial MAIL. To date their operations have had little impact on SWM. 
The Director of the WMD did comment that there was a data base of all Saighan canals in his office but that it was not accessible at the moment. He also stated that a register of all Mirabs would be created in the near future. ${ }^{39}$

The WMD office is a substantial recently constructed building. There are a total of four staff, of whom three are administrative, and the only staff member with a qualification or experience relevant to rural water supply is the Director himself. There was no evidence of any of the equipment needed to carry out either field or administrative work. The WMD is currently involved in establishing 7 stream gauging stations on the Bamyan River.

During the 2008 drought the WMD produced a paper at the request of the MEW. This paper described the impact of the drought on surface and sub surface water resources, and the reduction in irrigated areas. It also recommended measures to reduce the impact on communities. ${ }^{40}$

The Bamyan WMD has not been involved in either the KRBP or its successor the PARBP although launching of the PARBP in Bamyan is imminent. The Director demonstrated a good knowledge of the water resource situation in the Saighan Valley. He also advised that the PARBP staff had already carried out site inspections at five locations in Saighan. ${ }^{41}$

Past works carried out by the WMD have included the construction of two canals downstream of the Qarawna dam and the repair of a canal at Sukhta Chenar/Darwishan. In each of these activities, the WMD funded the works, developed the technical design and supervised the contractor. These works were carried out in 2007/8 and were opened by the DG in $2008 .{ }^{42}$

The Ministry of Agriculture Irrigation and Livestock has an office at Provincial level. This office is staffed by the Director and approximately 7 others ( 6 positions in cropping and one in animal husbandry). These staff have little involvement with the Saighan District but the Director did outline plans for four major activities for the district. Of these plans, two had direct relevance to water management.

The first was the construction of the Dar-e-Ujak canal which would take water from the Gazak area of Kahmard District to the lower parts of the Saighan Valley (Bayon Qoli area). This would provide sufficient water to irrigate 1000 ha. of land. The second was to become involved in watershed management activities in the upper catchment areas. The plans are still being developed by the provincial MAIL office. ${ }^{43}$ The estimated cost of the water diversion proposal is in the region of US\$1.5 million. The Director indicated that the money is available and has been approved at national level. ${ }^{44}$

\subsection{Stakeholders at River Basin Level}

The Panj- Amu River Basin Programme is a major stakeholder for water management in the Saighan valley. To date neither it nor its predecessor, the Kunduz River Basin Programme, has been involved in water management in the Saighan Valley, but the PARBP is to commence planning and implementation work in Bamyan Central District in the very near future. Only after will it begin

\footnotetext{
${ }^{39}$ Both registers of Mirabs and data bases of canals in the Province are kept by the WMDs in Badakshan and Takhar Provinces.

${ }^{40}$ This paper is undated and does not indicate who wrote it. The paper covers all Districts in Saighan. It is held in the Solidarités office at Saighan.

${ }^{41}$ This is highly unlikely as this was the first time that such inspections had been mentioned by any of the stakeholders involved in Saighan water management. The statement is included in this report for completeness. The 5 locations included Korsum dam, a dam site near Bayoni, Charagh Dan Canal, Deh Amon canal, and a dam site in Said Baba.

42 This is strange as at the meeting with the DG on 28 March 2010, no mention was made of this.

${ }^{43}$ The Director envisages an NGO like Solidarités or Helvitas implementing the plans!

${ }^{44}$ None of the other people consulted mentioned this and therefore all the statements made by the Director should be treated with caution.
} 
operations in Saighan..$^{45}$ It will take a lead role in social water management activities either becoming directly involved or by supporting other institutions such as NGOs to carry out the SWM planning and implementation. ${ }^{46}$

The SWM activities will be commenced before the infrastructural activities and will be similar in nature to those implemented in the KRBP. At this stage it is anticipated that interventions will start in 2011. The SWM interventions will be at both sub-catchment and river basin levels and will be using the river basin approach so the downstream water users will become stakeholders. ${ }^{47}$

The NGO Solidarités is both an existing and a potential stakeholder. Effective water management is essential to the land and crop management activities currently being advocated by Solidarités. Their present interventions in fields such as cropping and horticulture all are directly related to water availability and thus they have an interest in ensuring that the water resource is managed in a sustainable manner. The present LRRD project which Solidarités is implementing is due to finish in December 2011, and will overlap with the SWM activities of the PARBP.

Similarly, Europeaid is a stakeholder in that they are funding both the LRRD and the PARBP.

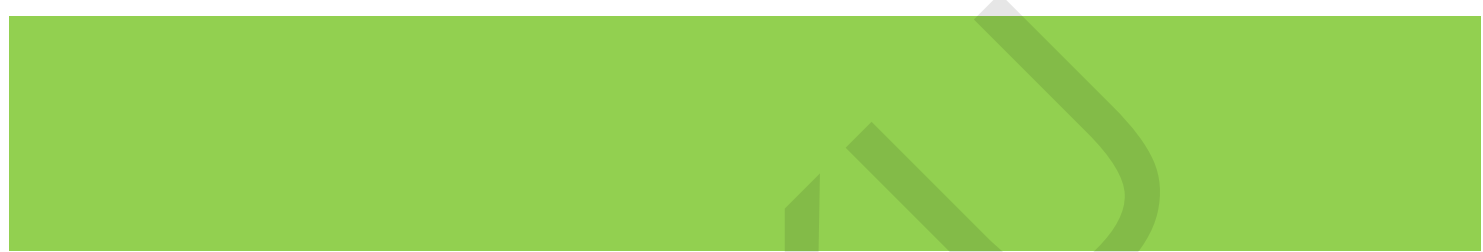




\begin{tabular}{|c|c|c|c|c|}
\hline Mullahs & Saighan & All communities & $\mathrm{L}$ & $\mathrm{L}$ \\
\hline Co-ops & Saighan & 2 in existence, 3 more proposed & $\mathrm{L}$ & $\mathrm{L}$ \\
\hline District Governor & Saighan & Oversees all development activity & $\mathrm{H}$ & M \\
\hline DDA & Saighan & Develops strategy, seeks funding & $\mathrm{L}$ & $\mathrm{M}$ \\
\hline Social Organisers & Saighan & Mobilises communities & $\mathrm{M}$ & $\mathrm{M}$ \\
\hline MAIL EOs & Saighan & Employed by MAIL & $\mathrm{L}$ & $\mathrm{M}$ \\
\hline UNHabitat & Saighan & Implements NSP projects & $\mathrm{M}$ & $\mathrm{L}$ \\
\hline NGOs & Saighan/Bamyan & Solidarités, COUK & $\mathrm{M}$ & $\mathrm{H}$ \\
\hline WMD & Bamyan & Plans/constructs water I/structure & $\mathrm{L}$ & $\mathrm{H}$ \\
\hline Prov. AIL & Bamyan & Responsible for in field w/managt. & $\mathrm{L}$ & $\mathrm{L}$ \\
\hline Prov RRD & Bamyan & Provides funds for development & $\mathrm{L}$ & $M / L$ \\
\hline PARBP & Kabul/Kunduz & Implements R/basin strategy & NA & $\mathrm{H}$ \\
\hline Europe Aid & Kabul & Funding body & $\mathrm{H}$ & $\mathrm{H}$ \\
\hline PARB Council & & Provides strategic direction & NA & $\mathrm{H}$ \\
\hline MEW & Kabul & Supervises WMD staff & $\mathrm{M}$ & $\mathrm{L}$ \\
\hline MAIL & Kabul & Supervises Prov. MAIL staff & $\mathrm{L}$ & $\mathrm{L}$ \\
\hline MRRD & Kabul & Makes strategic investment & $\mathrm{M}$ & $\mathrm{L}$ \\
\hline National Govt & Kabul & Implements the Water Law & $\mathrm{M}$ & $\mathrm{H}$ \\
\hline
\end{tabular}
H 
There is no "turn" system used at village level and farmers use water as they please. During the Daud government (late 1970's), the turn system was applied to the valley as a whole and the village was allocated one and a half days per month. At the moment the only people who are inconvenienced by water shortages are those farmers at the end of the canals who sometimes have to irrigate at night. Similarly the mill and mHEP operate only at night when flows are adequate to provide the energy needed.

There has never been a Mirab and all decisions regarding maintenance and other management issues, such as allowing water to be used by other villages, are made by the community. At one time, some five or more years ago, the police became involved to resolve a dispute over water with a neighbouring village. Details of this dispute were not clear and the other village was not named. There have been no such disputes since then.

Qarawna Village (CDCs I and II) has a CA of 1350 jerib and an average of 2.7 jerib per family. There is a major water storage (estimated capacity of approx $150 \mathrm{ML}$ ) immediately upstream from the CA. There is adequate water to irrigate all the CA, and annual periods of water shortage are usually limited to one month (May).

The community employs three Mirabs who work as a team across the entire CA. One of these three Mirabs are appointed by elders from each settlement and may be replaced if the community wishes. There is no Mirab bashi and one of the three is responsible for operation of water releases from the dam. ${ }^{49}$ There is no "turn system" operating within the village at the moment. Instead of allocating a specified period of time for water access to each farmer, the Mirabs ensure that there is equitable distribution. Although it was not specifically stated, this is most likely done by making observations of the crop condition and then, where deemed appropriate, making flows available to those crops where there appears to be water stress. Mirabs are paid "in kind" which is specified as one eightieth of the crop yield obtained by each farmer.

When the dam was constructed some 10 years ago, the institution which built it (Solidarités) insisted on the Qarawna community making an agreement with the communities immediately downstream from it. Under this agreement the communities of Nowabad and Khudadad Khil were to have access to any water in the dam which the Qarawna community did not require. The details of this agreement were documented and copies of this document were kept by each community and the DG. When asked if we could see the document, Mullah Kadir of Qarawna after first agreeing, could not locate it so the actual details were never available. At the moment the combination of the partly open sluice gate and the discharge from several leaks appears sufficient for the needs of the three communities (Qarawna, Khudadad Khil and Nowabad)..$^{50}$

One specific issue which is currently unresolved is that of accessibility for Qarawna CDC III communities located upstream of the dam during periods when the water level in the ponded area is high. At such times, sections of the access road between these three settlements are inundated and the only way to pass along the road to/from Deh Nula is by using a truck with a high clearance. ${ }^{51}$

The "turn" system which operated during the Daud era was gradually replaced by the present Mirab system as "the regulation imposed by government resulted in too much conflict"

\footnotetext{
${ }^{49}$ On each occasion that the dam was inspected, the sluice gate was partially open and it appeared that it was jammed with the opening/closing mechanism being not functional.

${ }^{50}$ For a more detailed description of the physical situation at the Qarawna dam see Annex 3

51 The farmers claim that it has always been possible to traverse the inundated sections but if the dam were at FSL there would be at least $3 \mathrm{~m}$ of water covering the lowest sections of the road. For further details see Annex3.

${ }^{52}$ Comment by several farmers/village elders at the FGM conducted at Qarawna on 1 April 2010.
} 
conflicts were not made available but probably resulted from the Qarawna community objecting to what they considered was a short "turn" allocated to them. ${ }^{53}$

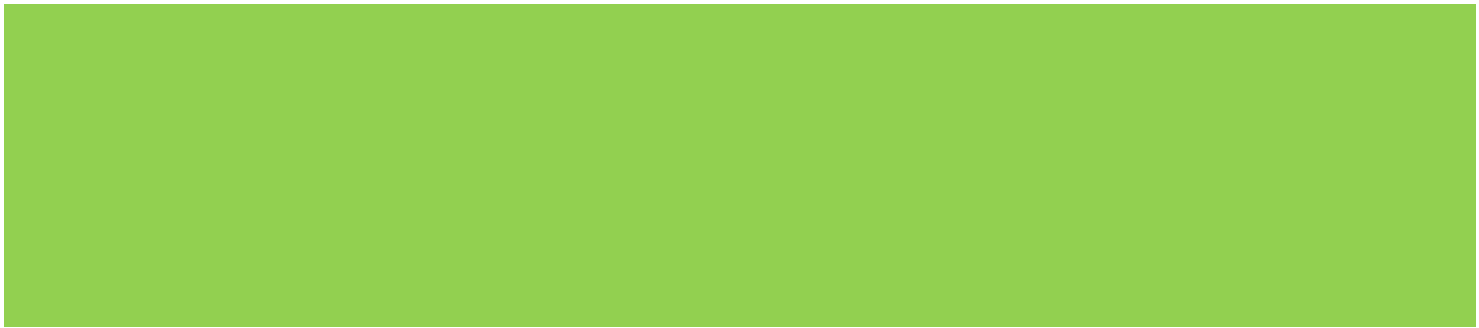


Maidanak irrigation area is a very new one with recently constructed infrastructure creating the potential to irrigate a previously unirrigated area located above Said Baba village where all the Maidanak farmers are originally from. Although a very small area, approximately $25 \mathrm{jerib}$, it has been the site of much investment with very expensive canals, aqueduct and tunnel to get water to it. This investment is going to waste as currently the head ditch is earthen and very little of the water diverted to it reaches the field.

Water from a reliable spring with a substantial yield is shared between farmers in the Maidanak area and the neighbouring village of Pushtawaz. The two communities have reached an agreement whereby Pushtawaz farmers who by far out- number Maidanak farmers, have access to the water in the day, leaving the Maidanak farmers full access at night. There is no Mirab or other formal management system. 


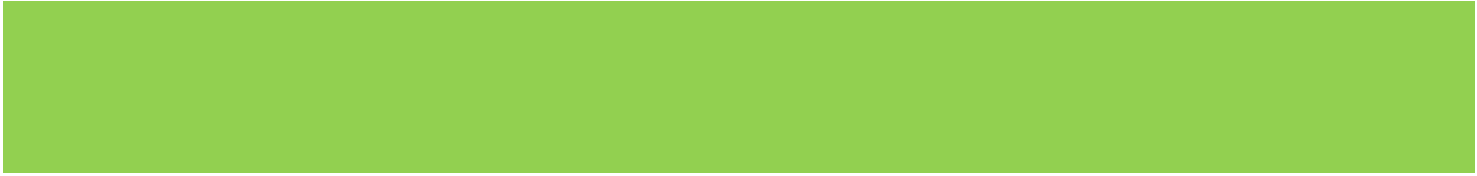


A number of stream bank protective walls have been constructed and much of the water course has been planted with vegetation. Some of the walls have obviously been constructed by a riparian farmer to protect his land. If this continues there will be potential for disputes to arise as the practice of protecting stream banks with structures, such as groynes and walls, can often transfer the erosion to another sector of the water course.

Many farmers and community leaders recognise the need for a more effective management system, and some urge for a return to the days when the entire valley was divided into zones with defined allocations for each zone. The community claim that there has never been any interest shown by government at any level in their water management problems. ${ }^{62}$

Khudadad Khil Irrigation area. It is located downstream from Qarawna and is on the right bank of the Saighan River. The average amount of land owned per family is 2.5 jerib on a total of 500 jerib of CA. Of the six villages which form the Khudadad Khil community, farmers from two of them (Baghi Miran and Khudadad Khil sub village) form the bulk of landowners in the irrigation area.

There is one Mirab for this irrigation area. Water distribution is his main function, and a system of 'turns" is practised with some of the smaller areas, having a "turn" as short as 15 minutes. Both the Mullah and the Shura play a role in resolving disputes peacefully. To carry out repairs and maintenance each family must provide one representative. De-silting of canals is undertaken annually.

In most years the Khudadad Khil community is requested by downstream farmers (presumably Nowabad) to release water. This occurs in mid June and the Khudadad Khil community always responds by assisting the community requesting the water.

Bayon Qoli Irrigation Area is a large area towards the lower end of the Saighan Valley. The settlement comprises 3 villages of which two (Bayon Qoli and Sabez Qala) contain the most irrigation land in the studied area. The leaders advised that there were a total of 500 families (Bayon Qoli 400 and Sabez Qala 100) in the settlements, but this is quite different from the figure of 315 obtained from other sources. The average holding per family is 2.6 jerib. However, the presence of a large area with high water tables reduces the cropping area per family to approximately 2 jerib per family. ${ }^{63}$

Water is diverted from both the Saighan River and the Charagh Dan stream with the irrigation areas being at the downstream end of both. As a result irrigated crops suffer extended dry periods particularly those dependant on the three canals drawing water from the Saighan River. There are five canal systems which each have their own CAs. Thus the system is a complex one with a need for good co-ordination and management.

Despite the complicated nature of the irrigation system there is no Mirab and the community manages the entire process with intervention by the Shura only when necessary. Each farmer is allocated a "turn" of the water as measured in time. The order of access to water from each canal is determined by lottery. Unauthorised diversion of water and conflicts do not occur. Any necessary maintenance is carried out by the community and, when major repairs or additions are needed, the Shura will take the leadership.

The days of the zoning system introduced by the Daud government are remembered fondly and the community unanimously regrets the dropping of the regulations. Under that system, Bayon Qoli was

\footnotetext{
62 This is debatable as the location of the irrigation area is adjacent to the DGs office and the DG is often consulted by communities on water supply matters

${ }^{63}$ At the focus group meeting the farmers advised that there was a total of 1800 jerib in the command area and that a total of 1600 jerib was irrigated. These figures vary from those estimated on the map where the areas are 1300 and 1000 jerib respectively.
} 
allocated 7 days per month of all flows in the Saighan River for 7 months each year, and 7 days for every 10 days of the Charagh Dan stream flows. There was no community based Mirab as the

overnment employed district based staff to supervise the allocations. ${ }^{64}$ There has been no visit by any government official in the water sector since $1978 .{ }^{65}$

Sar-e Tang Irrigation Area obtains its entire water supply from the Saighan River. It is the furthest downstream of all the sample villages and is 325 jerib in area with an average area of 1.2 jerib per family.

As for Bayon Qoli, the community remembers the Daud government introducing the zoning system for the valley, and is advocating its re-introduction. They claim that the original documents describing the regulations still exist. The past ten years have been ones of acute water shortages with (at most) three waterings being applied to wheat crops. The canals used to supply the irrigation area are approximately $3 \mathrm{~km}$ long and are earthen with high water losses. Like Bayon Qoli there is no Mirab and the community regulates the use of water.

In times of water stress, Khudadad Khil and Deh Amon both release water for emergency use in Sare-Tang but the amounts are minimal. 
Although the present Director of the WMD is focussed on infrastructure, the fact that the department produced a drought strategy in 2008 is evidence that they are aware of the need for planning albeit it in emergency situations.

The Ministry for Rural Rehabilitation and Development. MRRD has carried out capacity building at community level via the two social organisers who facilitate communication between the communities and other actors. These two workers would be very valuable in the event of a subcatchment water management structure being established as they both have a good knowledge of the social and physical environments.

The farming community. The community has very mixed feelings about the introduction of a sub catchment wide water management structure. It is very apparent that the lower catchment villages who are deprived of water will grasp at any straw that might improve their situation. When each community was asked what improvements to water management they would like to see, only one community nominated a sub catchment wide management structure.

\subsection{Discussion on Water Management}

Communities have adopted a number of different management strategies to regulate the use of irrigation water within their own areas. These range from a formal Mirab system which gives considerable powers to the Mirab, to one in which the community has empowered itself. Each of these strategies appeared to be working with an acceptable level of efficiency and social equity.

The most apparent failing of the system as implemented within a village was the reliance on units of time to measure water volumes. Such a method of flow measurement will inevitably lead to miscalculations which result in more water being delivered to land located on the upper reaches of a canal, than is delivered to the same area of land on the lower reaches. Some communities (eg Darwishan, Deh Aman/Sumucha, and Qarawna) deal with this by having village elders inspect all crops and, where necessary, allocating additional flows to crops exhibiting water stress. Other communities say that the unevenness of water distribution of water along a canal does not matter as each farmer has land at various points along the canal. Thus all farmers have land in the top, middle and lower sections, and therefore all farmers will get some extra water for their "top" land, and all farmers will get less water for their "bottom" land. Qarakhawal is one community which has made such a claim.

After each focus group consultation had concluded, satisfaction scores were allocated to each community. These scores were based on the perceived satisfaction of the community with the supply of irrigation water. It also took into account the length of dry period, the amount of water available during the irrigation season and the frequency of conflicts. Two scores were allocated. The first was for the degree of satisfaction within the community for the management of the water available to it, and the second was for the management of water within the valley. These scores are presented in the two tables ${ }^{66}$ below:

\begin{tabular}{|l|c|}
\hline \multicolumn{1}{|c|}{ Community } & $\begin{array}{c}\text { Satisfaction Score for } \\
\text { Water Management } \\
\text { Within the Village }\end{array}$ \\
\hline Maidanak & 8 \\
\hline Qarakhawal & 8 \\
\hline Sukhta Chenar & 8 \\
\hline
\end{tabular}

\footnotetext{
${ }^{66}$ Scores were allocated by the consultant sometimes in consultation with the Solidarités team and sometimes by himself. Scores were allocated on a scale of 0 to 10 with 0 representing total dissatisfaction, 5 representing "not happy but accepting of the management", and 10 representing "total satisfaction".
} 


\begin{tabular}{|l|l|}
\hline Qarawna & 7 \\
\hline Said Baba & 7 \\
\hline Darwishan & 7 \\
\hline Sumucha/Deh Aman & 7 \\
\hline Deh Nula/Nowabad & 6 \\
\hline Khudadad Khil & 8 \\
\hline Khudadad Khil/Baghi Mirran & 6 \\
\hline Bayon Qoli & 8 \\
\hline Sar-e Tang & 8 \\
\hline
\end{tabular}

The conclusions which can be drawn from these results are:

1. The water user is generally satisfied with the manner in which the water available to his community is managed.

2. There is no considerable variation between villages in the degree of satisfaction in the management of water within villages.

\begin{tabular}{|c|c|c|}
\hline Community & $\begin{array}{c}\text { Score for } \\
\text { W/Management } \\
\text { In the Valley }\end{array}$ & Explanation \\
\hline Maidanak & 9 & $\begin{array}{l}\text { Located in uplands; source is a spring which is } \\
\text { shared with } 1 \text { other community only. }\end{array}$ \\
\hline Qarakhawal & 7 & High in catchment \\
\hline Sukhta Chenar & 7 & $\begin{array}{l}\text { Reliable springs adjacent to the irrigated area; has } \\
\text { jurisdiction over stream flow. }\end{array}$ \\
\hline Qarawna & 8 & $\begin{array}{l}\text { High in catchment; has control over a major } \\
\text { storage; considerable recent investment in } \\
\text { infrastructure. }\end{array}$ \\
\hline Said Baba & 5 & $\begin{array}{l}\text { Suffers regular shortages due to upstream } \\
\text { diversions }\end{array}$ \\
\hline Darwishan & 4 & Immediate upstream neighbour controls all flows \\
\hline Sumucha/Deh Aman & 5 & Same as Said Baba \\
\hline Deh Nula/Nowabad & 4 & \multirow{3}{*}{$\begin{array}{l}\text { Located mid catchment and therefore has little } \\
\text { control over flows. Attempts to negotiate } \\
\text { agreements with } U / S \text { neighbours }\end{array}$} \\
\hline Khudadad Khil & 4 & \\
\hline Khudadad Khil/B. Miran & 4 & \\
\hline Bayon Qoli & 0 & \multirow{2}{*}{$\begin{array}{l}\text { Has no control over amount of water received from } \\
\text { upstream and as a result suffers frequent drought. }\end{array}$} \\
\hline Sa-e-Tang & 0 & \\
\hline
\end{tabular}


These scores indicate a very different pattern for satisfaction within the valley with the main conclusions being:

1. Satisfaction with the way water is managed in the valley is highest in the upper villages and lowest in the lower reaches.

2. Communities can be grouped into three basic groups according to their level of satisfaction with the way water is managed within the valley viz. 


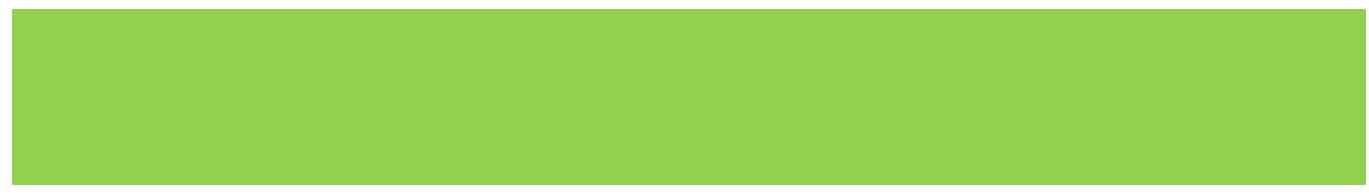




\section{Annexes}

Annex 1: Agenda for Focus Group Meetings

Date Canal/Village

PROGRAM

\begin{tabular}{|c|c|c|c|c|}
\hline Item & Activity & Details & Person/Speaker & $\begin{array}{c}\text { Time } \\
\text { Allocation }\end{array}$ \\
\hline 1 & $\begin{array}{l}\text { Opening and } \\
\text { Prayer }\end{array}$ & & Leader & 5 mins \\
\hline 2 & Introduction & $\begin{array}{l}\text { Purpose of SWM study } \\
\text { Conduct of the meeting } \\
\text { Introduction of participants }\end{array}$ & Solidarity leader & 10 mins \\
\hline 3 & SWM & Meaning and relevance of SWM & JS & 15 mins \\
\hline 4 & $\begin{array}{l}\text { History of the ( ) } \\
\text { Canal }\end{array}$ & $\begin{array}{l}\text { When constructed and by who, } \\
\text { Damage (flood etc), } \\
\text { Previous interventions (who, } \\
\text { what, when) }\end{array}$ & Village leaders & 30 mins \\
\hline 5 & Uses of the water & $\begin{array}{l}\text { Irrigation, humans, livestock, } \\
\text { industrial (mills), HEP, other, } \\
\text { priorities }\end{array}$ & Village leaders & 15 mins \\
\hline 6 & $\begin{array}{l}\text { Uses of Irrigation } \\
\text { water horticulture }\end{array}$ & $\begin{array}{l}\text { Crops (species, water } \\
\text { requirement, yields, pests, etc) } \\
\text { Fruit and veg - Pasture - Other - } \\
\text { (area grown, types, water } \\
\text { requirement, yields, home } \\
\text { consumption, sale, number } \\
\text { watering per crop). }\end{array}$ & Solidarity staff & 10 mins \\
\hline 7 & Water availability & $\begin{array}{l}\text { Seasonal variation, long term } \\
\text { trends, spatial distribution, }\end{array}$ & Solidarity staff & 30 mins \\
\hline 8 & Management & $\begin{array}{l}\text { (1) Shura, CDC, Mirab, } \\
\text { community, fees, "turn", } \\
\text { penalties, maintenance, } \\
\text { (2) Problems } \\
\text { (3) Suggestions } \\
\end{array}$ & JS & 45 mins \\
\hline 9 & Infrastructure & Suggestions & JS & \\
\hline 10 & $\begin{array}{l}\text { Proposed } \\
\text { legislation }\end{array}$ & Summary of relevant factors & JS & 20 mins \\
\hline 11 & Closure & Thanks and prayer & Leader & 5 mins \\
\hline \multicolumn{4}{|c|}{$\begin{array}{rr}\text { Total time } \\
\end{array}$} & 3 hours \\
\hline
\end{tabular}




\section{Annex 2: Site Inspection Report - Korsum and Doume Jangal Dams}

Date of Inspection $13^{\text {th }}$ April 2010

Both dams are located in the upper reaches of the Saighan River. Korsum dam is $10 \mathrm{~km}$ SW of Said Baba village and is located between the villages of Kalacha and Khoja Ganj, and Doume Jangal a further $9 \mathrm{~km}$ SW from Korsum and is between Kalacha and Doume Jangal villages.

Both dams were formed by rock slides caused by an earthquake in 1956. In both cases the slide came from the NW and inundated the Saighan River. In the case of the Doume Jangal Dam, an entire village was covered with (reportedly) a very high mortality rate.

Both of the storages have significant capacity (est. Korsum 400ML and Doume Jangal 350ML) which could have a significant impact on the water resources available for use in D/S irrigation areas. This volume would be adequate to provide 2 waterings of $30 \mathrm{~mm}$ to an area of approx 4500 jerib. (assuming $20 \%$ losses in transmission). It is not envisaged that any new land should be developed for irrigation but that existing areas where crops are continually moisture stressed in the months of May, June and July, should have supplementary watering.

1. Doume Jangal Dam.

At the time of inspection the dam was full to capacity and overflowing. The "embankment" is very broad based and was estimated to be in excess of $10 \mathrm{~m}$ in height with a freeboard of over $2 \mathrm{~m}$. No leaks around the toe of the D/S batter were observed, although discharge from the spillway may have concealed any leaks.

The dam was spilling through an excavated spillway located at the eastern end of the embankment. This spillway had a crest width of approximately $8 \mathrm{~m}$ and was over $30 \mathrm{~m}$ long. It appeared reasonably stable with only a few minor secondary erosion heads in it.

The overflow passes through irrigation areas at Khoja Khist and Kalacha where it is utilised for wheat and other crops.

The batters of the ponded area were stable with no signs of further landslips.

Fish were observed in the ponded area and there were signs that of small scale fishing activities.

2. Korsum Dam.

This dam is different in that it does not have a spillway and indications are that it spills very rarely if at all. There is a low point in the embankment on the northern end where minor overflows may have occurred in the past, but there is no constructed spillway. As the observed inflow was considerable and soaks were observed below the dam in the stream bed, the "embankment" must be sitting on a gravel/sand foundation with sub surface flows passing through it.

The "embankment" was estimated at being approximately $8 \mathrm{~m}$ high and the batter slopes appear stable.

To exploit the water resource contained in these two storages certain activities both social and structural, would be needed.

Doume Jangal. 


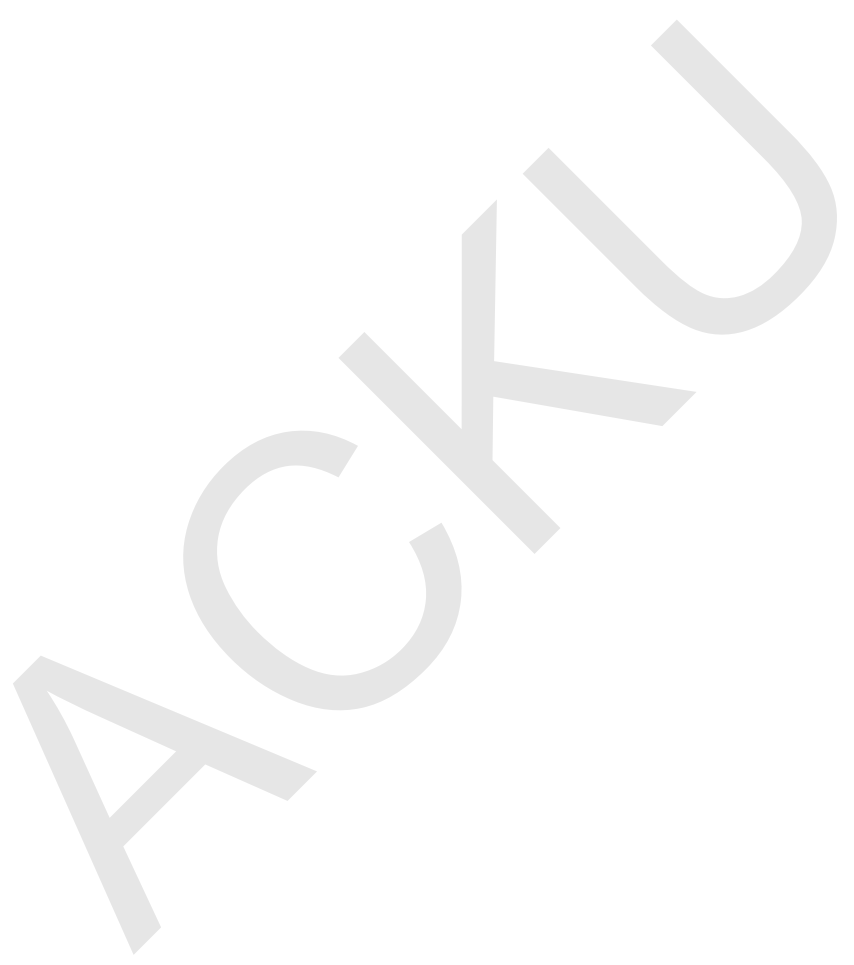




\section{Annex 3: Site Inspection Report - Qarawna Dam Location:}

The dam is located on the Qarawna River which is a tributary of the Saighan River. It is approx $6.5 \mathrm{~km}$ south-west from the Deh Nula Masjid which is on the main Saighan-Bamyan road.

GPS co-ordinates were not possible because of the steep chasm sides blocking the signal. A point approx 200m downstream of the dam embankment was recorded as: N 35 09.323' E 067 37.481'.

\section{Background/History:}

A comparatively large dam was constructed at this site by Solidarités c 2000. There are reports that it was constructed at the site of a (Russian built?) low level weir.

Water from the dam is used by farmers from the Qarawna II and III CDCs and by farmers in other areas commanded by the dam. All supply from the dam is by gravity. Apart from farmers in Qarawna who benefit most, the farmers from Nowabad, Khudadad Khil and De Nula would obtain some benefit. If releases of water are made in an appropriate manner, farmers from as far downstream as Sar-e-Tang could benefit.

The water is used primarily for irrigation with livestock and human domestic consumption being very much of secondary importance.

Many CDC Shuras and government officials are aware of the dam and its potential, and various officials have declared that the capacity should be increased by raising the crest and FSL.

Solidaritie requested the inspection and report as they have made a submission to ECHO for funding to rehabilitate the dam for both WASH and Irrigation purposes.

\section{Description of the Site.}

The dam was inspected on two occasions by the writer, firstly on 1 April 10, and again on the $10^{\text {th }}$ April 2010.

The dam is located in a very steep sided and narrow chasm with cliffs an estimated $100 \mathrm{~m}$ high on either side for it's entire length. These cliffs are of sandstone (?) origin and exhibit frequent fractures in the strata.

The dam is an earthen embankment with masonry batters on both the $\mathrm{U} / \mathrm{S}$ and $\mathrm{D} / \mathrm{S}$ sides. The spillway is concrete with a spill length of approx. $4 \mathrm{~m}$. and is located at the western end (LHS) of the embankment. The height of the crest above the streambed on the $\mathrm{D} / \mathrm{S}$ side is estimated at $18 \mathrm{~m}+/-$. and freeboard is estimated at $3 \mathrm{~m}$.

An iron turn-table on the crest of the embankment adjacent to the spillway controls the operation of a discharge gate valve at the toe of the $\mathrm{D} / \mathrm{S}$ batter.

An access road traverses the east side of the dam with sections of the road approx $3 \mathrm{~m}$ below FSL. This road provides access to Qarawna and Deh Nula etc, for three villages U/S from the dam. The point where the road crosses the embankment forms an emergency flood bypass which is approx $1 \mathrm{~m}$ above FSL..

The dam capacity was estimated to be in the vicinity of 100-150ML. and has the approx surface dimensions of $50 \mathrm{~m} \times 350 \mathrm{~m}$ and a (reported) maximum depth of $17 \mathrm{~m}$.

\section{Observations.}

1. There was a steady inflow from the stream entering the tail water. This was estimated to be in the region of $10-20 \mathrm{l} / \mathrm{sec}$.

2. A large amount of sediment deposit was present in the upper reaches of the ponded area. Rock and earth from the cliffs has also fallen into the ponded area. 
3. The embankment appears quite stable and there are no obvious leaks occurring under it.

4. At the time of inspection, the WL was about $5 \mathrm{~m}$ below FSL, and the spillway showed no signs of having ever operated. (This was later confirmed by the Qarawna mullah).

5. Sections of the road adjacent to the east side (RHS) of the ponded area showed signs of recent inundation and there had been works carried out recently to lift the road pavement to reduce the impact of rising water levels on access.

6. The gate valve appeared to be closed but there was still a substantial discharge at the outlet point.

7. There were no obvious signs that this discharge control facility is used. It was locked and there were a number of bolts missing from the structure.

8. Discharges were also occurring quite low down on the LHS. These flows were coming out of the rock strata adjacent to the buttress between the embankment and the cliff.

9. The combined flow of the discharges from the design outlet and the "buttress outlet" was sufficient to create a steady flow in the stream below the dam.

10. The $W L$ at the time of the first visit was about $500 \mathrm{~mm}$ below that at the time of the second visit (9 days).

11. The canal constructed to convey water from the dam to the command areas is seriously damaged by rock falls and there appears to have been no attempt to clear these falls. The location and design of this canal is flawed in that sections are located at the toe of scree slopes which are most unstable, and because parts of the canal should have been protected by including a concrete slab/roof in areas where there were potential rock-falls .

\section{Secondary Information.}

1. The dam is monitored regularly by a Mirab who is responsible for controlling discharges.

2. The dam is emptied (almost) ever year in order to supply flows to D/S irrigators.

3. The regular inundation of the road is a serious hindrance to farm operation.

\section{Water Usage.}

The dam is located on a water course which is a very important irrigation and domestic water source for 5-600 families and 400 ha of land. During high flow periods it would also supply water to another 270 families located further $\mathrm{D} / \mathrm{S}$.

It was reported to the writer that soon after construction, the communities of Qarawna I and II reached an agreement with the communities of Deh Nula, Khudadad Khil, and (maybe) Nowabad, whereby "when Qarawna farmers had filled their own requirements, the D/S communities were granted access to any water remaining". It was reported (Qarawna mullah 14/4/10) that this agreement had been documented, but when asked if a copy could be made, there was a negative response.

\section{Conclusions:}

The amount of stored water is reasonably constant, with the observed inflow being approximately equal to the combined discharges. This state is acceptable to the Qarawna communities as it enables them to utilise the small discharge without passing on any of the flow to $\mathrm{D} / \mathrm{S}$ communities. 
There were no indications that anyone is trying to manage the body of water in a logical and sustainable manner. The report that the Mirab does this is very spurious.

Increasing the capacity of the dam would be worthless as the leaks around the LHS abuttment will continue to cause significant losses to the point where the dam is at an (estimated) $5 \%$ of capacity. Repair of such leaks is a difficult process with there being no certainty of the outcome.

Over time the capacity of the dam will be gradually reduced by both siltation and further rock falls.

Access by U/S communities is a serious problem which is best overcome by lifting the level of the road using local material. The idea of trying to protect the road by building a masonry wall is not a good one.

The canal is not operating as designed.

\section{Recommendations.}

A. 
Annex 4: Kareez

Introduction.

Many parties are urging Solidarités to investigate and then if appropriate, construct a kareez ${ }^{67}$ or a number of them. These parties include the Saighan District Governor, the Director of MRRD and many communities (Qarawna, Deh Nula, and Qarakhawal) all advocated the construction of kareez as one way of solving the water shortage problems in the valley.

Kareez is the name given to underground structures designed to intercept shallow groundwater flows and pass it to the surface where it will be available for use for either human consumption or irrigation. They are said to be common in parts of southern Afghanistan and Iran but there are no reports of them in the northern or central parts of Afghanistan

During his mission the SWM Consultant inspected two sites above the Qarawna dam. These sites had been suggested as appropriate for kareez construction by the District Governor and the Qarawna Mullah.

\section{Site Description}

The location is approximately $9.5 \mathrm{~km} \mathrm{SW}$ of the Qarawna dam in Qarawna CDC I. The first possible site is just north of the village of Dana Sangchang, and the second is a further $500 \mathrm{~m}$ along the road towards Zargu Lugac village.

Both sites are located on colluvial outwash at the toe of steeper stony slopes. The geology is unknown. At the foot of the colluvial material is an alluvial flood plain through which the Qarawna stream passes.

Seepage areas across the colluvium, springs along the stream and high water tables indicate that the area is a discharge area for groundwater. Local reports (the Mullah) have it that water quality is good.

\section{Site Suitability for Kareez Construction.}

This report will not comment on the technical suitability for construction of a kareez. To determine the suitability the following investigations need to be undertaken:

1. A hydro geological survey to determine the potential yield and hydraulic conductivity of the aquifer.

2. A cost benefit analysis to determine if the construction and operation of the kareez would be economically viable.

3. An engineering design with complete costings.

In addition to the above, firm agreements would have to be made between communities where the kareez would be located, the communities where the transmission canals would be located, and the communities where the water would be used.

\section{Comments by the SWM Consultant}

1. A constant flow passes down the Qarawna stream to enter the Qarawna dam and then through the dam to the irrigation command areas below. Interception of the base flows by constructing a kareez at the site inspected would not increase the total amount of water available for irrigation as diversion of the base flow would merely reduce the discharge onto the flood plain and stream. Any canal system constructed to convey water to the dam would be performing the same function as the stream currently performs.

${ }^{67}$ In some places kareez are known as qanats 
2. A more cost effective method to exploit the water resource in the area would be to drain the flood plain using sub surface drainage. ${ }^{68}$ Such drains could be located to discharge into the stream at strategic points where the generated surface runoff could pass on down to the dam without re-entering the water table. It is unlikely that such drains would increase the amount of water available for irrigation but they would lower ground water tables and thus increase the area suitable for cropping. It would not be appropriate to excavate surface drains.

3. Examination of the literature on kareez reveals that most are constructed in environments which are arid and where the kareez discharge site is adjacent to the area/s where the water will be utilised. ${ }^{69}$ This is not the case for the proposed site.

4. The idea of exploiting groundwater resources in the Qarawna area using kareez has been mooted as a solution to water shortages as far away as $21 \mathrm{~km}$ (Sabez Qala and Bayon Qoli). On the way to such areas the conserved water will have to pass through a major storage and through a number of different communities via permeable streams and canals before it reaches its destination. Saighan communities are noted for their unwillingness to share resources particularly water, with other communities. The task of developing a workable agreement between these various communities would be a very challenging one and the pitfalls which could arise are numerous.

68 Depending on the soil structure, a network of sub-surface drains could be installed to lower the water table. Such drains could be slotted PVC pipes wrapped in geo-textile and surrounded by sand/gravel, or simple agricultural drains consisting of trenches with gravel placed in them and then backfilled with soil.

${ }^{69}$ Source http://en.wikepedia.org/wiki/kariz 
Annex 5: Efficient Water Use in Cropping 
comprises an outlet to the tank, a buried system of HDPE pipe, a system of stand pipes with faucets, and finally a hand held flexible hose which is used to fill the ditches surrounding each individual tree.

Such a system is both capital and labour intensive but it does result in water savings of over $50 \%$.

The water reservoir could be sited in a location where it could be filled by gravity from an existing channel, and if it still commands the orchard to be irrigated then no pumps would be needed. The capacity of the storage tank and the size of HDPE pipe would be determined by the size of the orchard and the water requirement of the trees.

To justify such an investment orchards with a minimum size of 3 jerib would be needed and unfortunately, this is not the case in SV where most commercial fruit growing is in areas of less than 1 jerib. However, if fruit growing is to become a major activity with land presently used for cereals being converted to fruit, then hose pipe irrigation would be a viable method of irrigation.

An added advantage would be that farmers using such a method would become familiar with the concept of applying specific volumes of water and not rely on "time" as a measurement.

6. 


\section{Annex 6: Water User Associations and River Basin Management}

River Basin Management has the following objectives:

1. The most efficient utilisation of water resources by all stakeholders,

2. Equitable allocation of water resources to all users including the environment, and

3. All stakeholders to have an input into the prioritisation of water uses and allocations.

The third objective can only be achieved within a community based administrative framework comprising, in the case of Afghanistan, a five tiered structure. The Water Law 2009 which provides for the establishment of RBM ${ }^{70}$ describes the following institutions:

A. The Supreme Council of Water Management.

Although the functions of this institution are not defined in the Water Law 2009, it is most likely that it will become the peak body at a national level for all issues involving water management.

B. River Basin Councils.

There will be five RBCs established in the country and the one that Saighan Valley will become part of is the Northeast RBC. The Council will be comprised of representatives from all identified stakeholders, of which the water using community is one. Their main function will be to facilitate integrated planning and involve all water users in the decision making process related to the management and development of water resources.

C. River Sub-Basin Councils.

There is provision for the formation of RSBCs under the Act, and Saighan Valley falls into the Kunduz RSBC. Whilst the Act specifically mentions "User representatives" as being included in the membership of RSBs, Article 17 which describes RSBC membership, only refers to "water use government institutions and other concerned agencies' reps in the river sub basin" (sic). Thus if this is the final definition of RSBC membership, then there is reason for concern as the majority of water users (i.e. farmers) would not be represented.

D. Water User Associations.

The Water Law also provides for the establishment of WUAs but does not give any details of their jurisdictions nor their functions and Powers.

Despite this omission, it is reasonable to conjecture how such a WUA could fit into the Saighan Valley situation and how it would relate to the institutions both above and below it in the organisational structure.

The Saighan Valley is a very well defined unit where the boundary of political jurisdiction (the District) matches the geographical boundary. Apart from some overlap of settlement areas within the irrigation areas there is a reasonable amount of coincidence between a settlement and the area farmed by farmers living in each settlement. Thus the basic unit for the management of each irrigation area would be the individual community. Each of these communities within the valley would form a Water User Group would formally elect several representatives. ${ }^{71}$ These representatives would then sit on a Water User Association which would be the organisation responsible for making decisions on how the water resource in the valley is managed.

\footnotetext{
70 The only copy of the Water Law available to the consultant was one entitled "Water Law Taqins Recent Draft - English 2007 version". This would seem to be an earlier draft and is probably not the final law as passed by Parliament and signed into law by Presidential decree.

${ }^{71}$ In other areas it has been found that communities accept the idea of electing three representatives - one with a high wealth ranking, one with a medium wealth ranking, and one either landless or low wealth. Rankings have been determined by the amount of land owned.
} 
Issues which crossed sub-catchment boundaries would be referred to RSBCs (or RBCs). Each RSBC would be comprised of representatives from each of the component WUAs, government, and other stakeholders such as the environment, industry and possibly health. 


\section{Annex 7: Measurement of Stream/Canal Discharge}

At the moment, Mirabs use the time of duration of a flow to measure the actual volume of water passing a particular point. This can lead to false measurements. For example, a flow of 60 minutes duration in the upper reaches of a canal will have a discharge different to a flow of 60 minutes duration in the lower reaches of the same canal, the difference being due to infiltration and evaporation losses in the intervening reaches.

To correct such errors the flow at set points should be measured. This can be done by a number of methods including the construction of weirs incorporating "V notches". However, the simplest way is to use the formula:

$$
\mathrm{Q}=\mathrm{V} \times \mathrm{A} / 1000
$$

Where $Q$ is the discharge in litres/second

$V$ is the velocity in metres/second

And $A$ is the cross-sectional area in $\mathrm{m} 2$.

"V" can be calculated by measuring the time it takes for a float such as a leaf or match to pass along a measured distance, and " $A$ " can be determined by measuring the physical dimensions of the canal (i.e. the wetted perimeter).

Obviously this method has many potential errors but, it has the advantages of being simple and inexpensive and one which could be carried out by Mirabs after adequate training. The process can be streamlined by calibrating the site where the measurement is carried out by developing a stage height curve. 


\section{Annex 8: Terms of Reference for the Water Resource Specialist}

Unfortunately the order in which inputs by the Water Resource Specialist and the Social Water Management Specialist was reversed from that which was originally planned. As a result this report contains many assumptions which are not based on adequate data. These assumptions include the actual amount of water available and technical issues such as drainage characteristics, plant water requirements, civil engineering related to water storages, and certain hydro-geological aspects.

Amongst other things the input by the Water Resource Specialist should cover the following: 